Article

\title{
New (Iso)quinolinyl-pyridine-2,6-dicarboxamide G-Quadruplex Stabilizers. A Structure-Activity Relationship Study
}

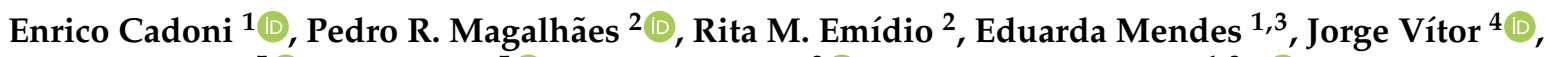 \\ Josué Carvalho ${ }^{5}$, Carla Cruz ${ }^{5}$, Bruno L. Victor ${ }^{2}$ and Alexandra Paulo ${ }^{1,3, * \mathbb{C}}$
}

1 Faculty of Pharmacy, Research Institute for Medicines (iMed.ULisboa), Universidade de Lisboa, Av. Prof. Gama Pinto, 1649-003 Lisboa, Portugal; en.cadoni@gmail.com (E.C.); ermendes@ff.ulisboa.pt (E.M.)

2 Faculty of Sciences, BioISI-Biosystems \& Integrative Sciences Institute, University of Lisboa, Campo Grande, C8 bdg, 1749-016 Lisboa, Portugal; prmagalhaes@fc.ul.pt (P.R.M.); fc53371@alunos.fc.ul.pt (R.M.E.); blvictor@fc.ul.pt (B.L.V.)

3 Department of Pharmaceutical Sciences and Medicines, Faculty of Pharmacy, Universidade de Lisboa, Av. Prof. Gama Pinto, 1649-003 Lisboa, Portugal

4 Department of Pharmacy, Pharmacology and Health Technologies, Faculty of Pharmacy, Universidade de Lisboa, Av. Prof. Gama Pinto, 1649-003 Lisboa, Portugal; jvitor@ff.ulisboa.pt

5 CICS-UBI-Centro de Investigação em Ciências da Saúde, Universidade da Beira Interior, Av. Infante D. Henrique, 6200-506 Covilhã, Portugal; josueocarvalho@gmail.com (J.C.); carlacruz@fcsaude.ubi.pt (C.C.)

* Correspondence: mapaulo@ff.ulisboa.pt

check for updates

Citation: Cadoni, E.; Magalhães, P.R.; Emídio, R.M.; Mendes, E.; Vítor, J.; Carvalho, J.; Cruz, C.; Victor, B.L.; Paulo, A. New (Iso)quinolinylpyridine-2,6-dicarboxamide G-Quadruplex Stabilizers. A Structure-Activity Relationship Study. Pharmaceuticals 2021, 14, 669.

https://doi.org/10.3390/ph14070669

Academic Editor: Andrea Porcheddu

Received: 29 May 2021

Accepted: 9 July 2021

Published: 13 July 2021

Publisher's Note: MDPI stays neutral with regard to jurisdictional claims in published maps and institutional affiliations.

Copyright: (c) 2021 by the authors. Licensee MDPI, Basel, Switzerland. This article is an open access article distributed under the terms and conditions of the Creative Commons Attribution (CC BY) license (https:/ / creativecommons.org/licenses/by/ $4.0 /)$.

\begin{abstract}
G-quadruplex (G4)-interactive small molecules have a wide range of potential applications, not only as drugs, but also as sensors of quadruplex structures. The purpose of this work is the synthesis of analogues of the bis-methylquinolinium-pyridine-2,6-dicarboxamide G4 ligand 360A, to identify relevant structure-activity relationships to apply to the design of other G4-interactive small molecules bearing bis-quinoline or bis-isoquinoline moieties. Thermal denaturation experiments revealed that non-methylated derivatives with a relative 1,4 position between the amide linker and the nitrogen of the quinoline ring are moderate G4 stabilizers, with a preference for the hybrid h-Telo G4, a 21-nt sequence present in human telomeres. Insertion of a positive charge upon methylation of quinoline/isoquinoline nitrogen increases compounds' ability to selectively stabilize G4s compared to duplex DNA, with a preference for parallel structures. Among these, compounds having a relative 1,3-position between the charged methylquinolinium/isoquinolinium nitrogen and the amide linker are the best G4 stabilizers. More interestingly, these ligands showed different capacities to selectively block DNA polymerization in a PCR-stop assay and to induce G4 conformation switches of hybrid h-Telo G4. Molecular dynamic simulations with the parallel G4 formed by a 21-nt sequence present in $k-R A S$ gene promoter, showed that the relative spatial orientation of the two methylated quinoline/isoquinoline rings determines the ligands mode and strength of binding to G4s.
\end{abstract}

Keywords: quinoline; isoquinoline; G-quadruplex ligands; $k-R A S ; c-M Y C$; telomere; SAR; pyridinedicarboxamide; molecular dynamics

\section{Introduction}

With the growing trend in the incidence of cancer [1], the need for developing effective and specific drugs to target cancer cells, for a less toxic and invasive therapy, is becoming increasingly important. One solution under debate is the modulation of gene expression by small molecules, supported by the evidence of the role in oncogenesis played by specific proto-oncogenes. In fact, mutations and translocations occurring within certain protooncogenes, such as $c-M Y C[2,3], k-R A S$ [4,5], and $c-K I T$ [6], have been frequently reported as a primary cause of cancer onset in several malignancies and for this reason, they have been widely studied as potential therapeutic targets [6-8].

It was demonstrated that the promoter regions of these genes, notably rich in guanine residues, are prone to fold into G-Quadruplexes (G4s) [9-12]. These non-canonical 
structures arise when four guanines of a G-rich tract are bound together via Hoogsteen hydrogen-bonding, forming the so-called G-quartet or G-tetrad. G4s are formed when two or more tetrads are stacked on top of each other, in an arrangement further stabilized by the presence of a coordinating cation, generally potassium [13]. Besides in proto-oncogenes, G4-forming sequences have also been identified in various other areas of the genome, particularly in the telomeric region [14]. The formation of telomeric G4 could also constitute an obstacle to the action of telomerase, the enzyme which re-synthesizes the terminal part of the chromosomes and has a central role in the aging process and in cancer development $[15,16]$. The high abundance of G4-forming sequences at the promoter level of genes involved in carcinogenesis, their prevalence in telomeric DNA regions, and their presence in RNA transcripts, suggests an important role of the G4 in the fine regulation of gene expression [17-19] as well as post-transcriptional and epigenetic modulation [20]. Therefore, the research efforts focused in small-molecules and oligonucleotide derivatives [21] that induce and stabilize G4-formation, has been seen as a promising approach to identify new therapeutic agents [19,22-25]. This is of utmost importance, considering the numerous evidences of G4-formation in vivo, which suggests a concrete physiological role of these structures in cells [26-28].

Among the small-molecule binders, an established family of ligands based on the bis-quinolinyl skeleton, was shown to have a high affinity and selectivity for G4 structures [24]. The use of pyridine or naphthyridine as a central module, combined with a carboxamide with bond rotation impairment, forces the ligand to adopt a highly beneficial V-shape conformation, consequently maximizing the interaction with the target G4 [15,29-31]. A paradigmatic model of this chemotype is given by the ligand 360A (2a), a N-methylbisquinolinium-pyridine-2,6-dicarboxamide, which was shown to be a potent and selective G4-stabilizer. The molecule displayed a binding preference to telomeric G4 (h-Telo), both in vitro and in human cells, and antiproliferative effects at a low micromolar concentration in telomerase-positive human cancer cell lines [15,32]. As a possible mechanism of action, Boussin and colleagues proposed that the ligand is able to induce Rad51-dependent aberrations at the telomeric level (telomere loss and doublet), and promote sister telomere fusions upon G4-stabilization [33].

Circular dichroism (CD) studies with 2a showed that the V-shaped structure, which was suggested to be maintained by the formation of intramolecular hydrogen bonds between the pyridine nitrogen and the $\mathrm{NH}$ - carboxamide linkers, can vary with the type of cations and anions present in solution [29,34]. Additionally, it was shown that the ligand is able to kick-off a potassium ion from the h-Telo G4. This study provided additional insights regarding the interaction of the ligand with the h-Telo G4. The observed ion ejection may induce either a G4 conformational change to an antiparallel structural arrangement, or the disruption of a quartet of the hybrid G4 [35].

Later studies also performed by CD, suggested that the binding of $2 \mathbf{a}$ to h-Telo G4 is accomplished in a 2:1 ligand:DNA stoichiometry [36]. Besides its well-known preferential affinity to h-Telo [32], 2a has been reported also to bind to other relevant G4-forming sequences, such as those in promoter region of $c-M Y C$ gene, for which molecular modelling studies suggest a end-stacking mode of binding [37]. Moreover, Van Dyck and co-workers reported its successful use in lymphoblastoid cell lines with the modulation of p53 mRNA transcripts [38].

Given the well-established nature of $\mathbf{2} \mathbf{a}$ as G4-ligand, and the simplicity and affordability of its synthesis, a wide range of applications featuring this ligand and its derivatives were reported by numerous research groups active in the field. For example, derivatives of 2a were successfully employed as alkylating and cross-linking agents of G4-DNA, either by employing visible light for the efficient photo-alkylation of $c-K I T$ and $c-M Y C$ G4 DNA, in the presence of a proximate G4-binding photosensitizer, or for the UV-induced photocrosslinking to h-Telo when linked to benzophenone or phenyl-azide moieties $[39,40]$. Other applications featuring $\mathbf{2} \mathbf{a}$ derivatives were extended beyond the canonical therapeutic context for which this ligand was initially designed. For example, this G4 ligand was 
also used in the development of fluorophore-ligand conjugates applied to fluorescence sensing of G4-DNA [41], in optical probes for G4-sensing, in functionalization with biotin tag to build a bait-molecule for fishing, in the identification of binding-DNA sequences [42], and even as an efficient anion fluorescence sensor [43]. Moreover, dimeric derivatives of 2a, featuring a higher binding affinity for telomeric G4-DNA, were also reported, increasing the ability of the ligand to target contiguous quadruplex structures [36,44].

Despite the numerous bis-quinoline derivatives reported as G4 ligands (reviewed in [24]), a systematic study elucidating the structure-stabilizing activity relationship (SAR) of the pyridine-2,6-dicarboxamide family of ligands is still missing. In this work, we aimed to shed light on the SAR of various bis-(iso)quinolinyl-pyridine-2,6-dicarboxamides, testing their ability to efficiently stabilize G4-DNA sequences of relevant human genome regions ( $k$-RAS, $c-M Y C$, h-Telo) over double-stranded DNA sequences. Thermal denaturation experiments of the targeted sequences in the presence of ligands, circular dichroism (CD)-titration experiments, biochemical assays (PCR-stop assay), as well as molecular modelling studies were used to study the influence of the carboxamide linker position in the quinoline/isoquinoline skeleton on the binding of the ligand to different G4 structures.

\section{Results and Discussion}

\subsection{Synthesis of Pyridine-2,6-dicarboxamide Derivatives}

In a first step, a library of simple pyridine-2,6-dicarboxamides $(\mathbf{1 b} \mathbf{b} \mathbf{h})$ was prepared by reacting 2,6-pyridinedicarbonyl dichloride with the respective aminoquinoline or aminoisoquinoline in toluene, at reflux temperature (Scheme 1A), according to previous literature reports $[43,45]$. Compound 1a was prepared by reaction of 2-aminoquinoline with the dichloride using THF (dry) as solvent, in presence of DIPEA as a proton scavenger. The compounds were obtained pure with a yield of $50-94 \%$. Then, $N$-methylation of $\mathbf{1 a}-\mathbf{h}$ was attempted by reaction with $\mathrm{CH}_{3} \mathrm{I}$ at room temperature in a solvent mixture of acetone:DMF 1:1, followed by filtration and washing of the formed yellow precipitates with ice-cold $\mathrm{MeOH}$. [43] In these conditions, only compounds $1 \mathrm{c}, 1 \mathrm{e}, 1 \mathrm{~g}$ and $\mathbf{1 h}$ afforded, without further purification and with yields of $51-62 \%$, the pure quinolinium iodide salts $\mathbf{2 a}, \mathbf{2 c}, \mathbf{2 d}$, and $\mathbf{2 b}$, respectively (Scheme 1B). The synthesis of compounds $\mathbf{2} \mathbf{b}-\mathbf{d}$ is here reported for the first time.

\subsection{G4 Thermal Stabilization Induced by Compounds}

As a first step to evaluate the interaction of the synthesized molecules to G4-DNA and to have an idea of the stabilization effect of these molecules, a Fluorescence Resonance Energy Transfer (FRET) melting assay was initially performed on TAMRA/FAM-labelled oligonucleotides (Please refer to Supplementary Table S1 for the sequences). Although methylated compounds generally performed better in terms of stabilization, we found that derivatives with amide linker in positions 6 and 4 of quinoline moiety (compounds $1 \mathbf{d}$ and $1 \mathrm{e}$, respectively) showed a modest stabilizing activity of promoter $k-R A S \mathrm{G} 4\left(\Delta \mathrm{T}_{\mathrm{m}}=8.0^{\circ} \mathrm{C}\right)$ and h-Telo $\left(\Delta \mathrm{T}_{\mathrm{m}}=18.0\right.$ and $11.8^{\circ} \mathrm{C}$, respectively) at a concentration of $5 \mu \mathrm{M}$ (Table 1 and Supplementary Figure $\mathrm{S} 1$ ). It should be noted that these compounds share the same relative 1,4 position between the amide linker and the nitrogen of the quinoline ring, which may contribute to an increased binding to the G4-DNA as a result of the additional basicity of quinoline nitrogen and its consequent extended protonation at $\mathrm{pH}$ 7.4.

Table 1. FRET-Melting $\Delta \mathrm{T}_{\mathrm{m}}$ values for $k$-RAS G4 and h-Telo G4 at $0.2 \mu \mathrm{M}$ FAM/TAMRA-labelled DNA concentration, in presence of the non-methylated dicarboxamide derivatives.

\begin{tabular}{ccccccccccc}
\hline & \multicolumn{7}{c}{ FRET $\Delta \mathbf{T}_{\mathbf{m}}\left({ }^{\circ} \mathbf{C}\right)^{\mathbf{a}}$} \\
\hline Ligand $(\mathbf{5 . 0} \boldsymbol{\mu} \mathbf{M} / \mathbf{2 5} \mathbf{~ e q})$ & $\mathbf{1 a}$ & $\mathbf{1 b}$ & $\mathbf{1 c}$ & $\mathbf{1 d}$ & $\mathbf{1 e}$ & $\mathbf{1 f}$ & $\mathbf{1 g}$ & $\mathbf{1 h}$ \\
\hline \multirow{2}{*}{ Sequence } & $k-R A S$ & $<0.5$ & $1.0 \pm 0.2$ & $3.0 \pm 0.5$ & $8.0 \pm 0.2$ & $8.0 \pm 0.1$ & $1.8 \pm 0.2$ & $<0.5$ & $<0.5$ \\
& $\mathrm{~h}-\mathrm{Telo}$ & $<0.5$ & $1.8 \pm 0.2$ & $2.8 \pm 0.4$ & $18.0 \pm 0.3$ & $11.8 \pm 0.2$ & $4.0 \pm 0.3$ & $<0.5$ & $<0.5$ \\
\hline
\end{tabular}

${ }^{\mathrm{a}}$ Experiments performed in cacodylate buffer $60 \mathrm{mM} \mathrm{K}^{+}, \mathrm{pH}$ 7.4. DNA G4 melting: $k$-RAS $=49.0 \pm 0.2^{\circ} \mathrm{C} ; \mathrm{h}-\mathrm{Telo}=56.9 \pm 0.2^{\circ} \mathrm{C}$ 
A. $\mathrm{Ar}-\mathrm{NH}_{2}+\mathrm{Cl}$

\begin{tabular}{|c|c|c|c|c|c|}
\hline Comp & $\mathrm{Ar}$ & Yield & Comp. & Ar & Yield \\
\hline $1 a^{*}$ & & $60 \%$ & $1 e$ & & $50 \%$ \\
\hline $1 b$ & & $89 \%$ & $1 \mathrm{f}$ & & $94 \%$ \\
\hline $1 c$ & & $70 \%$ & $1 \mathrm{~g}$ & & $56 \%$ \\
\hline $1 d$ & & $69 \%$ & $1 \mathrm{~h}$ & & $66 \%$ \\
\hline
\end{tabular}

B.
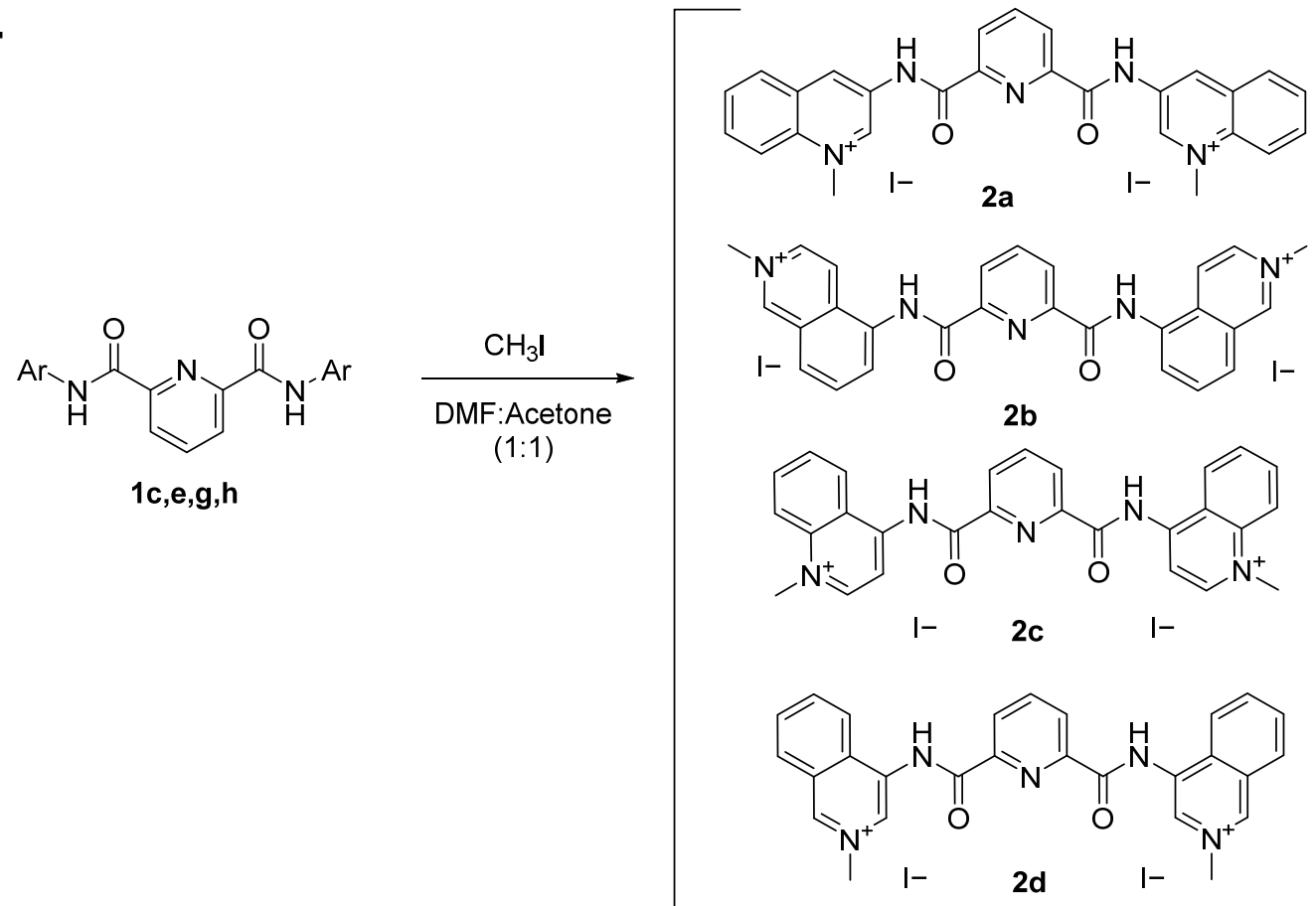

Scheme 1. Synthetic route for pyridine-2,6-dicarboxamide derivatives. (A). Toluene, $110{ }^{\circ} \mathrm{C}$ in reflux, overnight. $(\mathbf{B})$. $\mathrm{CH}_{3} \mathrm{I}$, DMF:acetone (1:1), 1-5 days, RT. * For compound 1a, another synthetic route was followed, refluxing the mixture in THF as solvent in presence of DIPEA (please refer to material and methods section). 
Upon insertion of a positive charge, all the $N$-methylquinolinium derivatives tested (2a-d) displayed preferred stabilization of the G4 sequences when compared to duplex DNA (T-loop). Most compounds showed a good G4 stabilization with concentrations starting on $1 \mu \mathrm{M}$ or 5 eq (Table 2), whereas 2a showed a good capacity to stabilize G4 at even lower concentrations, as already reported [15]. This result suggests an increased interaction of the ligand with the negatively charged DNA backbone, as reported by Pradeepkumar and co-workers for a naphthyridine-bisquinolinium derivative [30].

Table 2. Melting temperature variations $\left(\Delta \mathrm{T}_{\mathrm{m}}\right)$ values for the tested sequences in the presence of the methylated dicarboxamide derivatives, obtained by FRET-melting assay.

\begin{tabular}{|c|c|c|c|c|c|c|c|c|c|c|c|c|c|}
\hline \multicolumn{14}{|c|}{ FRET $\Delta T_{m}\left({ }^{\circ} \mathrm{C}\right)^{a}$} \\
\hline \multirow{2}{*}{\multicolumn{2}{|c|}{$\begin{array}{l}\text { Ligand } \\
\text { (eq) }\end{array}$}} & \multirow{2}{*}{\multicolumn{3}{|c|}{$2 a$}} & \multicolumn{3}{|c|}{$2 b$} & \multicolumn{3}{|c|}{$2 \mathrm{c}$} & \multicolumn{3}{|c|}{$2 \mathrm{~d}$} \\
\hline & & 0.5 & & 5 & 5 & 12 & 25 & 5 & 12 & 25 & 5 & 12 & 25 \\
\hline$\Xi$ & $k-R A S$ & $14.0 \pm 0.3$ & $32.8 \pm 0.2$ & $35.6 \pm 0.3$ & $4.0 \pm 0.2$ & $9.0 \pm 0.1$ & $11.1 \pm 0.2$ & $11.8 \pm 0.2$ & $16.6 \pm 0.2$ & $18.2 \pm 0.2$ & $15.0 \pm 0.2$ & $23.1 \pm 0.1$ & $26.1 \pm 0.2$ \\
\hline 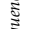 & h-Telo & $1.1 \pm 0.2$ & $13.2 \pm 0.2$ & $18.8 \pm 0.3$ & $2.3 \pm 0.1$ & $8.0 \pm 0.3$ & $10.1 \pm 0.1$ & $9.8 \pm 0.2$ & $13.1 \pm 0.1$ & $14.7 \pm 0.1$ & $15.1 \pm 0.1$ & $20.1 \pm 0.2$ & $22.7 \pm 0.2$ \\
\hline E. & $t$-Loop & $2.0 \pm 0.1$ & $5.6 \pm 0.1$ & $6.5 \pm 0.1$ & $<0.5$ & $<0.5$ & $1.8 \pm 0.2$ & $<0.5$ & $0.7 \pm 0.1$ & $1.2 \pm 0.1$ & $<0.5$ & $1.5 \pm 0.1$ & $2.5 \pm 0.1$ \\
\hline
\end{tabular}

${ }^{a}$ Experiments performed in $60 \mathrm{mM} \mathrm{K}^{+}$cacodylate buffer, $\mathrm{pH} 7.4$ with $0.2 \mu \mathrm{M}$ of oligonucleotide. G4 DNA melting: $k$-RAS $=49.0 \pm 0.2{ }^{\circ} \mathrm{C}$;

h-Telo $=56.9 \pm 0.2{ }^{\circ} \mathrm{C} ; \mathrm{t}$-Loop $=53.2 \pm 1.0^{\circ} \mathrm{C}$.

To further validate the stabilization induced by $\mathbf{2 a}-\mathbf{d}, \mathrm{CD}$-melting assays were performed by following the $\mathrm{G} 4$ denaturation at the maximum $\mathrm{CD}$ wavelength, confirming the results previously obtained in FRET-melting assay (Table 3). FRET and CD melting were employed as complementary techniques to study the ligand-induced thermal stabilization of the ligands. As FRET uses dyes to measure the $\Delta \mathrm{Tm}$, it is a common trend in this type of studies to use an additional technique to confirm the results, such as UV and CD melting, as occasionally the $\Delta \mathrm{Tm}$ values observed are due to unspecific interaction of the ligands with the dye, rather than direct G4 binding [46]. Overall, a concentration-dependent effect on the stabilization was observed for most ligands as higher concentrations led to a greater thermal stabilization of the G4 structure. In general, methylated compounds display a higher affinity for parallel $\mathrm{G} 4$, as shown by the higher $\Delta \mathrm{T}_{\mathrm{m}}$ values obtained in the presence of $c-M Y C$ and $k-R A S$ sequences as compared to h-Telo. For compound 2a we performed CD melting experiments at the new CD max after structural transition $(262 \mathrm{~nm})$ but could not obtain a sigmoidal melting curve, nor a two-state transition. This suggests that the newly obtained conformation is highly stable, probably due to a strong stabilization effect induced by the ligand.

Table 3. Melting temperature variations $\left(\Delta \mathrm{T}_{\mathrm{m}}\right)$ values for the tested sequences in the presence of the methylated dicarboxamide derivatives, obtained by CD-melting assay.

\begin{tabular}{|c|c|c|c|c|c|c|c|c|c|c|c|c|c|c|c|c|c|}
\hline & \multicolumn{17}{|c|}{$\mathrm{CD} \Delta \mathrm{T}_{\mathrm{m}}\left({ }^{\circ} \mathrm{C}\right)^{\mathrm{a}}$} \\
\hline & \multirow{2}{*}{$\begin{array}{l}\text { Ligand } \\
\text { (eq) }\end{array}$} & \multicolumn{4}{|c|}{$2 a$} & \multicolumn{4}{|c|}{$2 \mathrm{~b}$} & \multicolumn{4}{|c|}{$2 \mathrm{c}$} & \multicolumn{4}{|c|}{$2 \mathrm{~d}$} \\
\hline & & 1.0 & 5.0 & 10 & 25 & 1.0 & 5.0 & 10 & 25 & 1.0 & 5.0 & 10 & 25 & 1.0 & 5.0 & 10 & 25 \\
\hline छ & $k-R A S$ & $>40$ & $>40$ & $>40$ & $\begin{array}{l}\mathbf{P} \\
\end{array}$ & $3.0 \pm 0.2$ & $12.2 \pm 0.2$ & $15.1 \pm 0.2$ & $\begin{array}{l}\mathbf{P} \\
\mathrm{P}\end{array}$ & $13.8 \pm 0.3$ & $35.9 \pm 0.1$ & $37.1 \pm 0.1$ & $>40$ & $12.6 \pm 0.4$ & $>40$ & $>40$ & $>40$ \\
\hline 气ू̆ & h-Telo & $3.5 \pm 0.1$ & $12.2 \pm 0.3$ & Topology & Change & $1.7 \pm 0.2$ & $4.4 \pm 0.2$ & $6.9 \pm 0.2$ & $9.2 \pm 0.2$ & $3.3 \pm 0.1$ & $9.0 \pm 0.1$ & $9.0 \pm 0.2$ & $10.8 \pm 0.3$ & $6.8 \pm 0.2$ & $14.9 \pm 0.2$ & $19.8 \pm 0.4$ & $27.0 \pm 1.3$ \\
\hline 苛 & $c-M Y C$ & $35.7 \pm 1.3$ & $>40$ & $>40$ & $>40$ & $2.7 \pm 0.2$ & $5.3 \pm 0.1$ & $7.0 \pm 0.2$ & $9.7 \pm 0.2$ & $8.0 \pm 0.2$ & $24.1 \pm 0.1$ & $25.0 \pm 0.1$ & $29.4 \pm 0.1$ & $11.8 \pm 0.2$ & $31.2 \pm 0.2$ & $34.4 \pm 0.2$ & $>40$ \\
\hline
\end{tabular}

${ }^{a}$ Experiments performed with $10 \mu \mathrm{M}$ of oligonucleotide in $20 \mathrm{mM}$ lithium cacodylate buffer supplemented with $\mathrm{KCl}$ and $\mathrm{LiCl}$, keeping a constant ionic strenght of $100 \mathrm{mM}$, pH 7.2, following the $\mathrm{CD} \lambda_{\max }$ for each sequence: $265 \mathrm{~nm}(k-R A S$ and $c-M Y C) ; 290 \mathrm{~nm}$ (h-Telo). DNA melting: $k-R A S=48.3 \pm 0.2{ }^{\circ} \mathrm{C} ; \mathrm{h}-\mathrm{Telo}=59.6 \pm 0.9^{\circ} \mathrm{C} ; c-M Y C=50.4 \pm 1.9^{\circ} \mathrm{C} . \mathbf{P}=$ DNA precipitation.

Regarding $c-M Y C$ parallel G4, all ligands beside $\mathbf{2} \mathbf{b}$ stabilized the structure for more than $20^{\circ} \mathrm{C}$, even at low concentrations, as is the case of $\mathbf{2 a}$. In the case of $k-R A S$ parallel G4, similar results were obtained, with $\mathbf{2} \mathbf{b}$ being the less potent stabilizer, and the remaining ligands presenting $\Delta \mathrm{T}_{\mathrm{m}}$ values greater than $20^{\circ} \mathrm{C} . k-R A S$ was indeed the most stabilized G4 structure when compared to $c-M Y C$ and h-Telo, with the latter being the structure for which the ligand-induced thermal stabilization was less evident.

Overall, both techniques indicate for all G4-DNA structures, an induced thermal stabilization activity trend of $\mathbf{2 a}>\mathbf{2 d}>\mathbf{2} \mathbf{c}>\mathbf{2 b}$. Also, the relative position of the quinoline nitrogen and the amide $-\mathrm{NH}$, seems to play a role in G4 stabilization. The two most active compounds (2a and $\mathbf{2 d}$ ) show the common structural feature of having a relative 
1,3-position between the charged methyl-quinolinium/isoquinolinium nitrogen and the amide linker.

Finally, the selectivity of methylated compounds for G4-DNA over double-stranded (ds) DNA, was assessed. For doing so, $\mathrm{T}_{\mathrm{m}}$ of the FAM/TAMRA-labelled G4 sequence of $k$-RAS complexed with the ligands was recorded in presence of increasing concentrations of competing dsDNA, up to 125 -fold. For all the tested compounds, the presence of the competing DNA showed neglectable destabilization of the G4-ligand complex, thus confirming the high selectivity of the compounds for G4-DNA (Figure 1).

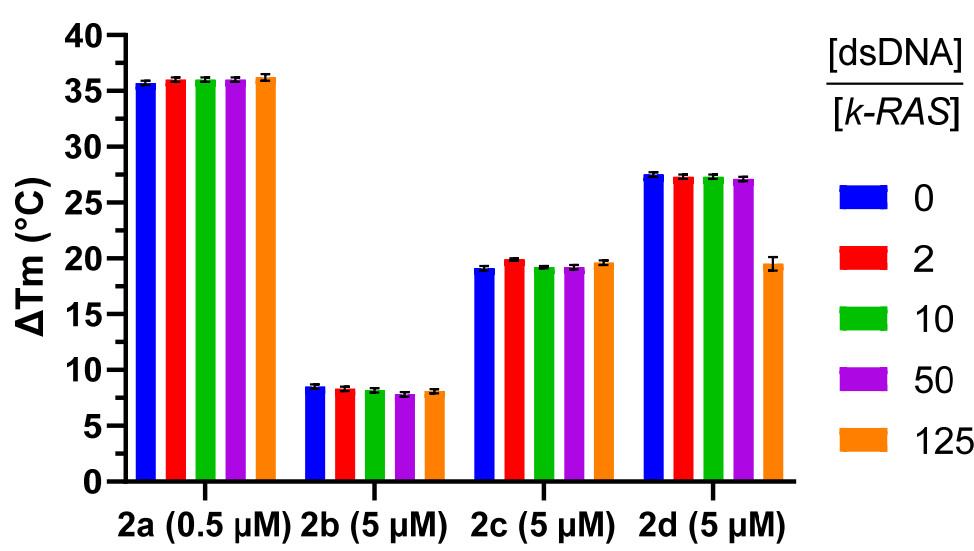

Figure 1. FRET-melting competition assay results for compounds $\mathbf{2 a}-\mathbf{d}$ at $0.5 \mu \mathrm{M}(\mathbf{2 a})$ and $5 \mu \mathrm{M}$ (2b-d) complexed with $k$-RAS G4 $(0.2 \mu \mathrm{M})$, challenged with increasing concentrations of non-labeled 26ds DNA (dsDNA) (0.4 to $25 \mu \mathrm{M})$ competitor. Experiments performed in potassium cacodylate buffer $\left(60 \mathrm{mM} \mathrm{K}^{+}, \mathrm{pH} 7.4\right)$.

\subsection{G4 Conformational Changes Induced by G4 Ligands 2a-d}

To retrieve additional information about the binding of the best ligands to G4s, we performed CD-titration experiments. Sequence h-Telo folds into a hybrid-type G4 structure in $\mathrm{K}^{+}$solution as suggested by its characteristic $\mathrm{CD}$ signature containing a positive band at $290 \mathrm{~nm}$, a shoulder peak at $265 \mathrm{~nm}$ and a weak negative at around $240 \mathrm{~nm}$ (Figure 2) [47]. CD-titration experiments on $\mathbf{h}$-Telo suggest that ligand $\mathbf{2 a}$ is able to induce conformational switch upon binding to the target, switching from a hybrid (3+1) topology to a parallel topology (appearance of the typical signature $\lambda_{\max }=264 \mathrm{~nm}$ ) (Figure 2A). These results contrast with what has been reported previously by Marchand and colleagues [35] where $2 a$ was suggested to convert h-Telo from a hybrid-type to an antiparallel topology in $\mathrm{K}^{+}$ solution. However, the sequence used was longer (24 nt) than that used in our study $(21 \mathrm{nt})$ and the potassium concentration was lower $\left(10 \mathrm{mM} \mathrm{K}^{+}\right)$. It is well known that sequence composition, length and salt concentration strongly affect the G4 topology of telomeric G4s [47-49]. Surprisingly, this behavior was not preserved by the other methylated derivatives, as even in large ligand excess, the characteristic signature of hybrid G4 $\left(\lambda_{\max }=290 \mathrm{~nm}\right)$ is maintained. Ligands $\mathbf{2} \mathbf{b}$ and $\mathbf{2 c}$ seem to interact with h-Telo as suggested by the slight ellipticity alteration, particularly around $260 \mathrm{~nm}$, but the overall topology seems to be maintained (Figure 2B,C). In the case of ligand 2d (Figure 2D), the G4 topology seems to be interconverted into an antiparallel structure as suggested by the strong negative band at $260 \mathrm{~nm}$ and a weak positive one around $240 \mathrm{~nm}$ following ligand titration. The conformational switches observed may however be incomplete, and mixed conformations can exist in the mix, as suggested by the lack of sharp signals. CD is a technique that lacks high-resolution when compared with others such as NMR or X-ray crystallography, therefore we cannot ascertain whether there are more than one G4 conformation in solution upon ligand binding. 

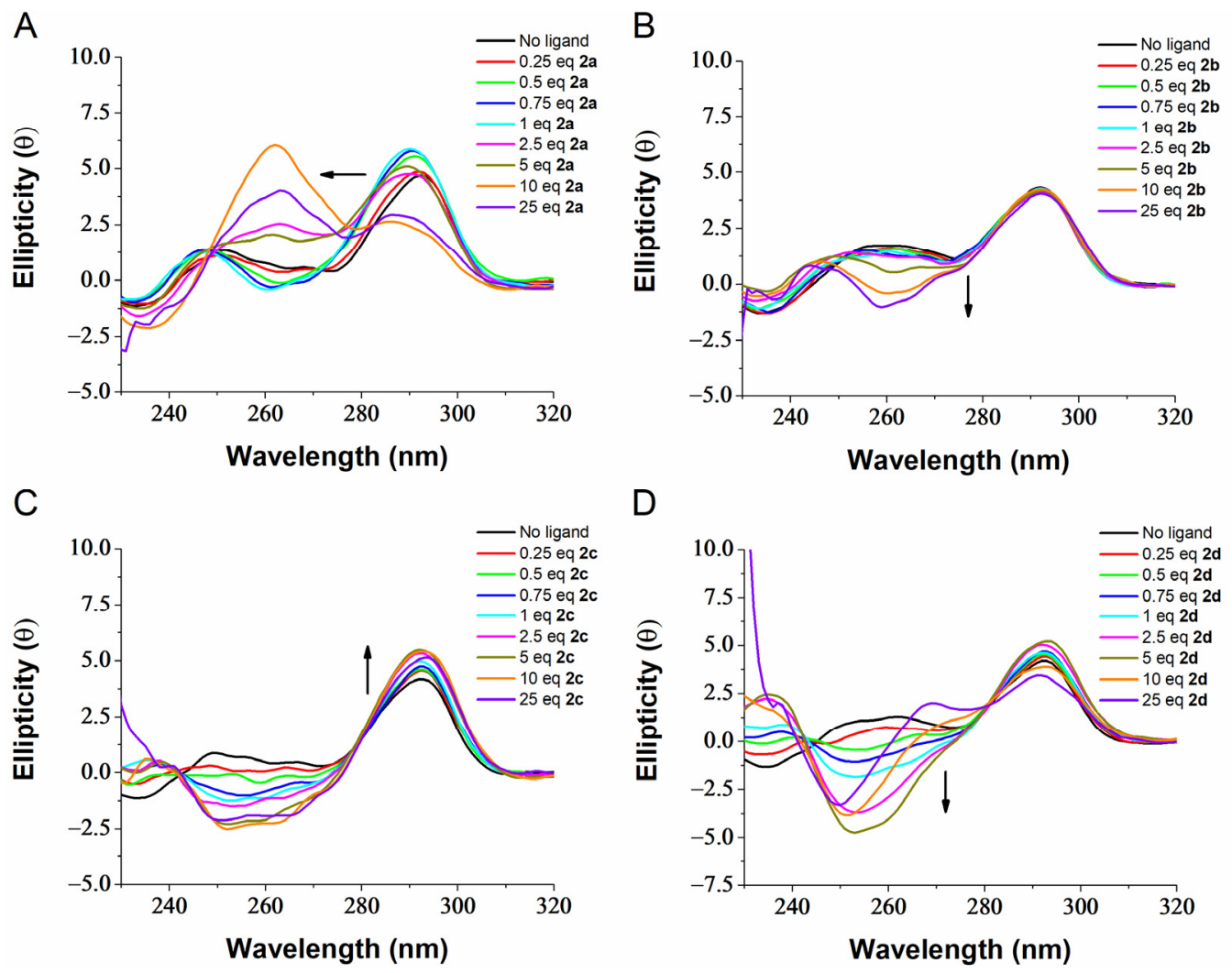

Figure 2. CD titration of h-Telo in presence of increasing equivalents (0-25) of compound $2 \mathbf{a}(\mathbf{A}), \mathbf{2 b}(\mathbf{B}), 2 \mathrm{c}(\mathrm{C}), \mathbf{2 d}(\mathbf{D})$, at a concentration of $10 \mu \mathrm{M}$, performed in $20 \mathrm{mM}$ lithium cacodylate containing $10 \mathrm{mM} \mathrm{KCl}$ and $90 \mathrm{mM} \mathrm{LiCl}$.

In the case of $c-M Y C$, it folds into a typical parallel G4 as shown by the positive band at $260 \mathrm{~nm}$ and the negative band at $240 \mathrm{~nm}$ (Supplementary Figure S5). Upon titration with the ligands, only a minor ellipticity variation was observed, suggesting ligand binding without affecting or interconverting the G4 structure. Indeed, $c-M Y C$ parallel G4 structure is very stable in the $\mathrm{K}^{+}$conditions used and one of the most stable G4s studied [50]. $k$-RAS on its hand, folds into a parallel-stranded G4 structure similarly to $c-M Y C$ (Figure S6), but upon titration with the ligands, a significant decrease in the ellipticity could be observed, particularly in the case of $\mathbf{2 b}, \mathbf{2} \mathbf{c}$, and $\mathbf{2 d}$ (Supplementary Figure S6B-D). This signal decrease was accompanied by the appearance of a CD band around $295 \mathrm{~nm}$ that suggests structural interconversion and possibly the formation of a hybrid G4 topology.

\subsection{Taq Polymerase Inhibition by G4-Ligands}

To evaluate the ability of the compounds in blocking DNA replication upon G4stabilization, a polymerase chain reaction (PCR)-stop assay using the G4-forming 27nucleotide sequence (Pu27) present in the wild-type promoter region of the $c-M Y C$ oncogene (see sequences in Supplementary Table S3) was performed according to the methodology previously reported [51]. The test is commonly used to evaluate the concentration of ligand necessary to induce the more stable loop-isomer involving G-tracts 2-3-4-5 and block DNA polymerase activity by inhibiting DNA hybridization at G-tract 5 [51]. Consistently with FRET-melting experiments, the non-methylated compounds did not show a significant activity up to $50 \mu \mathrm{M}$ concentration, even in the case of the best stabilizers of the series, 1d and 1e (Supplementary Figure S8A). On the other hand, and further confirming the results obtained with FRET and CD-melting analyses, the two more potent methylated compounds, $\mathbf{2 a}$ and $\mathbf{2 d}$, proved able to block polymerase activity at a concentration of 5 and $10 \mu \mathrm{M}$, respectively (Figure $3 \mathrm{~A}$ ). In contrast, the weaker stabilizing ligands $\mathbf{2 b}$ and $\mathbf{2 c}$, inducing a low/moderate $\Delta \mathrm{T}_{\mathrm{m}}$ in both FRET and CD melting assays, did not display any activity up to a concentration of $50 \mu \mathrm{M}$, in line to what was obtained for the non-methylated 
1d-1e. When a mutated sequence at G-tract 3 is used in place of native Pu27 (G13,14 $\rightarrow$ A mutation), the primer elongation is maintained in the presence of $\mathbf{2 d}$, even at high excess of ligand (Figure 3B) similarly to that observed for the related compound 307A [52], thus confirming that the polymerase blockade mechanism is ascribed to G4-stabilization rather than to non-specific interactions of the ligand with the DNA primer or with the enzyme. However, the more potent G4-stabilizer, compound 2a, was also able to stop polymerization of the mutated sequence (Figure 3B and Supplementary Figure S8B). A possible explanation is the ligand $2 \mathrm{a}$ to be also able to induce the formation of the less stable G4 loop isomer involving G-tracts 1-2-4-5 and in this way block hybridization of primers and subsequent replication by polymerase. To investigate this hypothesis, the $C D$ spectra of Pu27mut sequence were recorded in the PCR buffer, in the absence and presence of $\mathbf{2 a}$, confirming the capacity of $\mathbf{2 a}$ to induce the formation of a DNA structure with a CD profile suggesting a parallel G4, that is, with a negative band around $240 \mathrm{~nm}$ and a positive band around $260 \mathrm{~nm}$ (Supplementary Figure S7), as previously reported for the G4 isomer 1-2-4-5 [53,54]. To exclude any unspecific mechanism of polymerization inhibition by $2 \mathbf{a}$, we performed another assay with a sequence mutated in tract-3 and 5, the Pu27mut2 (see sequence in Supplementary Table S3), this one unable to form a G4. Figure 3C shows that polymerization of this sequence is inhibited only at high concentrations of $\mathbf{2 a}$. This may be due to ligand binding to hybridized primers or even single strand oligonucleotides, blocking the binding of Taq polymerase to the primers. In fact, looking to results of the FRET-melting assay in Table 2, ligand $\mathbf{2 a}$ is the one showing highest affinity to bind and stabilize the DNA duplex structure t-Loop.
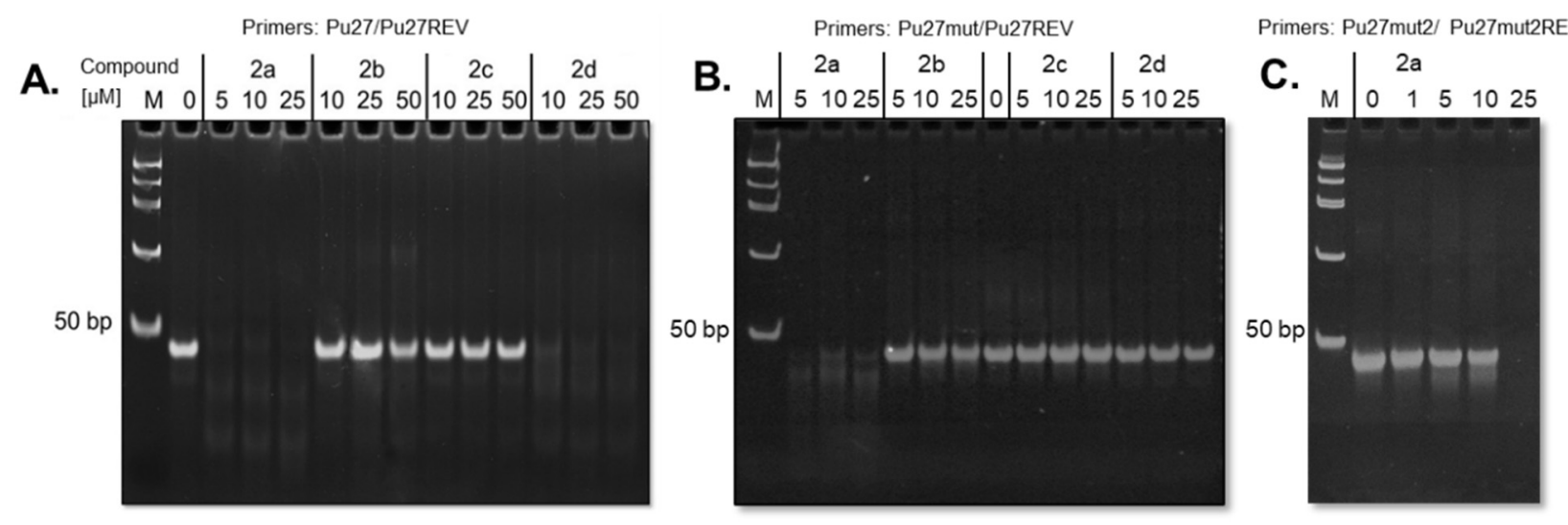

Figure 3. Polyacrylamide gels stained with ethidium bromide showing the effect of compounds on polymerization of DNA constructs. (A) Compounds $\mathbf{2 a}-\mathbf{d}$ in presence of $c-M Y C$ promoter wild-type sequence (Pu27); (B) compounds 2a-d in presence of $c-M Y C$ promoter sequence mutated in G-tract 3 (Pu27mut); (C) increasing concentrations of compound 2a in presence of $c-M Y C$ promoter sequence mutated in G-tracts 3 and 5 (Pu27mut2). In absence of compound (0 $\mu \mathrm{M})$, the $43 \mathrm{bp}$ PCR product is formed. M: PCR molecular weight marker.

\subsection{Molecular Dynamics}

To structurally characterize the interaction of $\mathbf{2} \mathbf{a}, \mathbf{2} \mathbf{b}, \mathbf{2} \mathbf{c}$, and $\mathbf{2 d}$ ligands with the $k-R A S$ molecule, we have performed long replicate MD simulations on a 1:1 ratio. In each replicate simulation, the compounds were randomly placed around the $k$-RAS parallel structure (PDB ID: PDB 5i2v). This was done to assure that each simulation was unbiased from any other replicate simulation. The initial $250 \mathrm{~ns}$ were not considered for the data analysis of the simulations, since only after this simulation time the complexes reached an equilibrium conformational state (Supplementary Figure S9).

To evaluate the convergence of the conformational space sampled by the ligand: $k$-RAS complex during the MD simulations of each system, we built root mean square deviation (RMSD) histograms calculated from the production trajectories. As can be seen in Figure 4, where we have the probability density of the conformations visited 
during the MD simulations for each compound, compound $\mathbf{2 a}$ adopts a lower range of conformations, when compared to all the other compounds. While for compound $2 \mathbf{a}$ we can observe one single peak, indicating a highly populated conformation, in compounds $\mathbf{2 b}, \mathbf{2 c}$ and $\mathbf{2 d}$, at least two highly populated peaks of conformations can be identified. This observation clearly indicates that the convergence of the interaction conformations adopted by compound 2a is much higher when compared to all the other compounds.

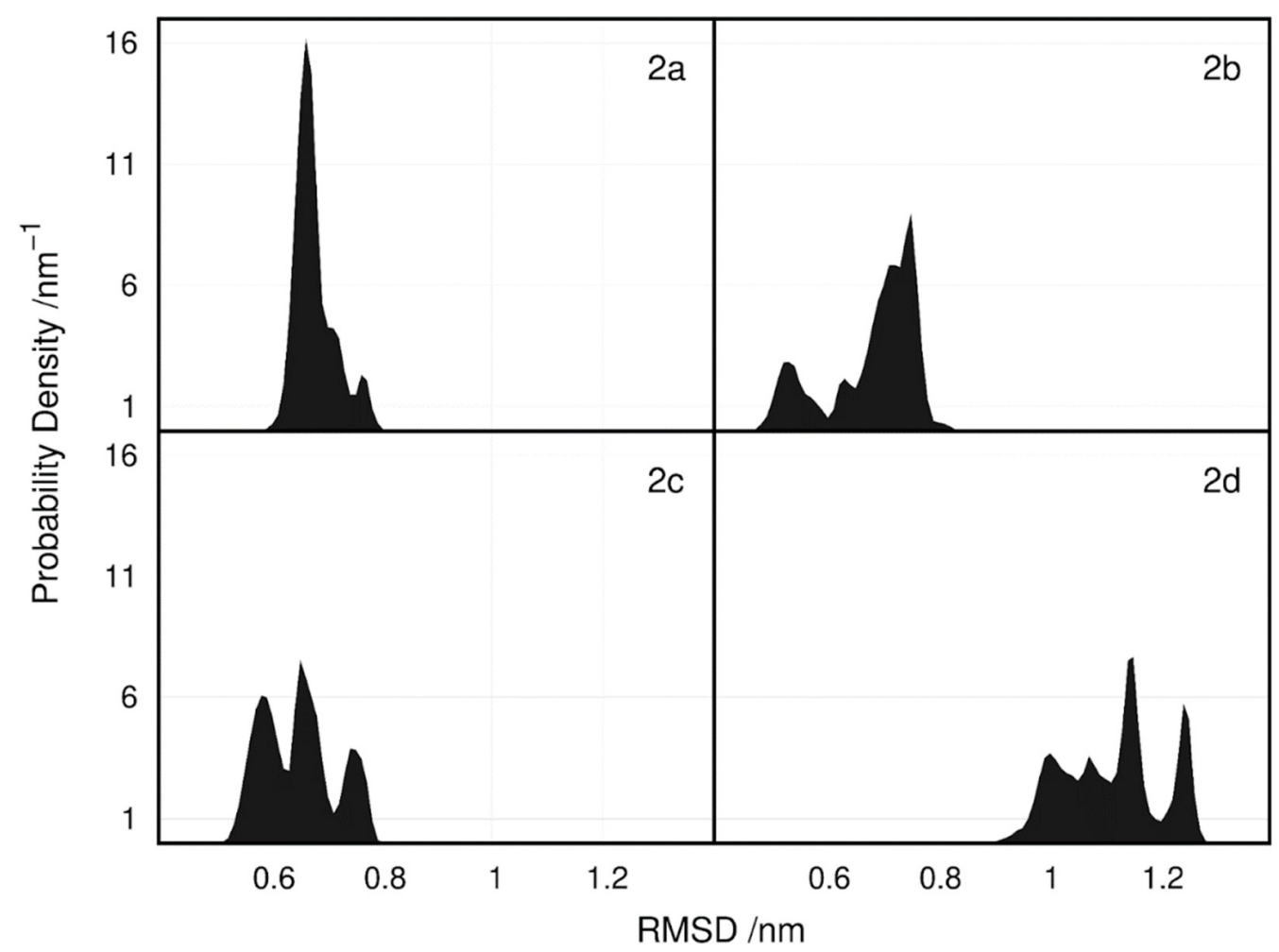

Figure 4. Probability density of the RMSD calculated for all replicate simulations of the different ligands $+k-R A S$ complexes. RMSD values were calculated taking as reference, the initial conformation of the complex of the first replicate for each simulated system.

To identify the preferred interaction configurations between the different compounds and $k$-RAS G4, the number of contacts between the two partners was calculated. Results are presented in Figure 5 and Supplementary Figures S11-S14, where $k-R A S$ residues were colored accordingly. Regarding compound $\mathbf{2 a}$, we can see that both the top and bottom regions of the $k-R A S$ molecule, close to its $3^{\prime}$ and $5^{\prime}$ terminal, respectively, are the regions showing the highest number of contacts. By visually inspecting the MD trajectories of the different replicates for this compound, we could verify that in replicates $1,2,4$, and 5 , compound 2a binds the $k-R A S$ at its top, closer to the $3^{\prime}$ terminal, while in replicate 3 , the most prevalent configuration shows an interaction of the ligand at the bottom surface, close to the $5^{\prime}$ terminal. Overall, adenine 1 , guanine 6 and 11 , and adenine 17 showed to be the preferred spots of interaction for this compound. Regarding compound $\mathbf{2} \mathbf{b}$, we can also clearly identify that the region of $k-R A S$ with more interactions was the side loop groove close to adenine 14 and 15 . The visual inspection of the trajectories of the different replicate MD simulations indicates that in replicates 2,3, and 4, compound $\mathbf{2 b}$ interacts preferably with this region of the DNA molecule. This interaction configuration is quite distinct from what was observed in replicate 1 and 5 , where the compound $\mathbf{2 b}$ binds respectively the top and bottom of the quadruplex, with the compounds establishing contacts with the guanine tetrad of $k-R A S$. In what concerns compound $2 \mathrm{c}$, both the top and the bottom regions of k-RAS G4 are the regions with a higher number of contacts. The visual inspection of the different replicate MD simulations indicates that in replicates 1 and 2, compound $\mathbf{2 c}$ binds 
to the bottom of the G4, while in replicates 4 and 5, the ligand preferably binds at its top. In replicate 3 , we could observe that compound $2 \mathrm{c}$ binds also at the side region of the G4 close to residues 12 and 17 . Finally, regarding compound $\mathbf{2 d}$, we clearly see that the preferred region of interaction with $k-R A S$ G4 is the bottom region close to the $5^{\prime}$ terminal. The visual inspection of the different trajectories indicates that in replicates 3 and 5 compound $2 d$ preferably binds the side region of $k$-RAS (between residues 15 and 19), in replicates 2 and 4 the interaction is mostly done at the bottom region close to the $5^{\prime}$ terminal, while in replicate 1 the preference for interactions is observed at the top of $k-R A S \mathrm{G} 4$, close to the $3^{\prime}$ terminal. Overall, these results confirm the conclusions previously taken from the analysis of the RMSD histograms, where compound 2a shows a higher convergence of pose interactions to $k-R A S$ when compared to all the other tested compounds.

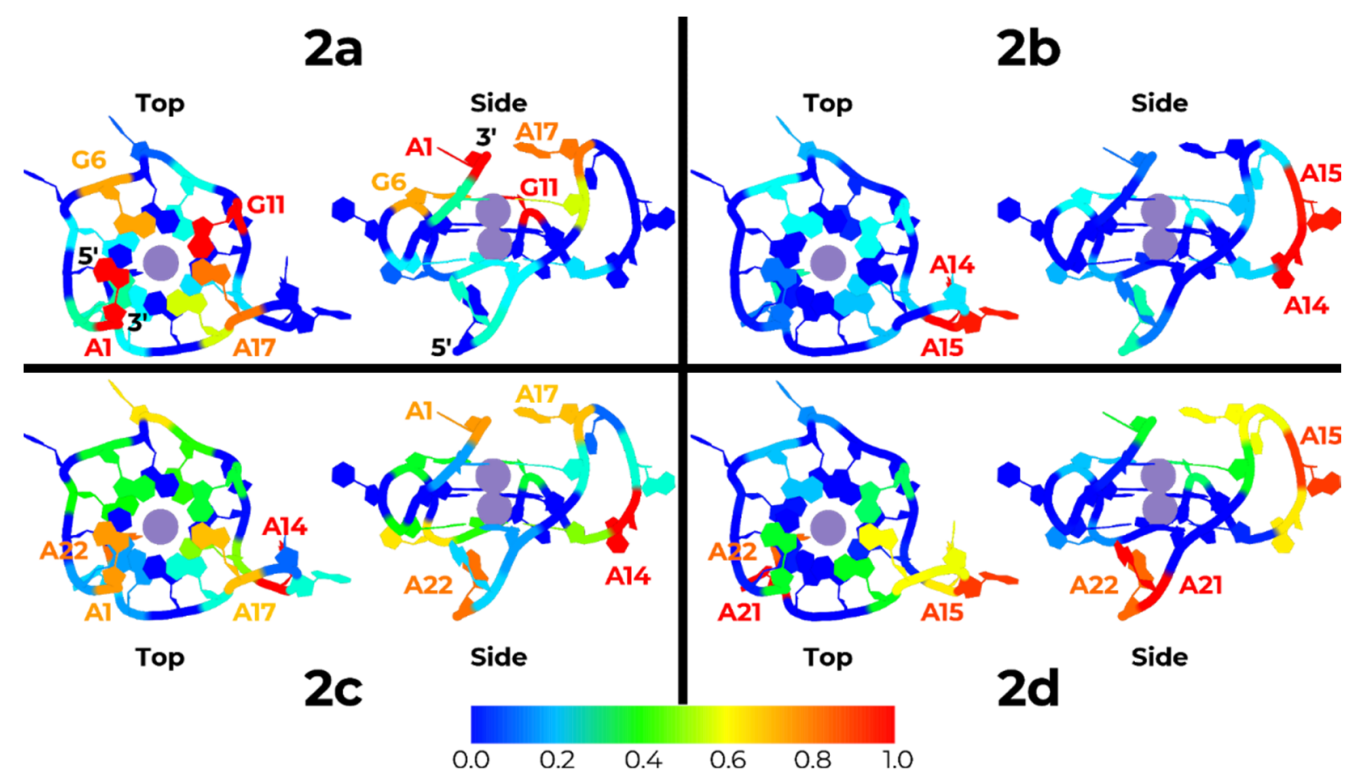

Figure 5. Cartoon representation of the structure of $k-R A S$ (top-view on left and side-view on the right) colored according to the normalized number of contacts determined from all the MD simulations (red to dark blue representing the highest number of contacts to the lowest number of contacts).

From the previous analysis, it is however difficult to identify a specific binding pose that could be seen as a representative of interaction between each one of the compounds and $k$-RAS G4. Therefore, we have analyzed the binding free energy of each compound throughout all the replicate simulations to identify a representative lowest binding affinity pose. To achieve this goal, we performed MM/PBSA calculations every 5 ns of simulation for all replicates and systems and identified the part of the trajectory of the replicate where a lower value for the interaction of the compound and the $k-R A S$ G4 was observed. Ultimately, from these sets of conformations, we selected a representative of the interaction between $k-R A S$ and each compound (Figure 6 and Supplementary Figure S10).

In the selected lowest binding energy representative conformation of compound 2a with $k$-RAS G4 we can see that the compound stacks in a planar configuration at the bottom region of the G4, close to the $5^{\prime}$ terminal. A perfect stack between the pyridine, the two quinoline groups, and the guanine-rich core of the parallel G4 is achieved. Interestingly, both the positively charged $N$-methylated groups in the two quinolines are facing the outward region of the core of the G4, directed to the negatively charged phosphate groups, evidencing a strong electrostatic attractive effect (see Table 4). Additionally, it is also possible to observe that one of the quinolines is double stabilized by the aromatic rings of guanine 20 and adenine 21, in an intercalating aromatic configuration that restrains the movements of this group, and consequently stabilizes the entire molecule on this conformation. 


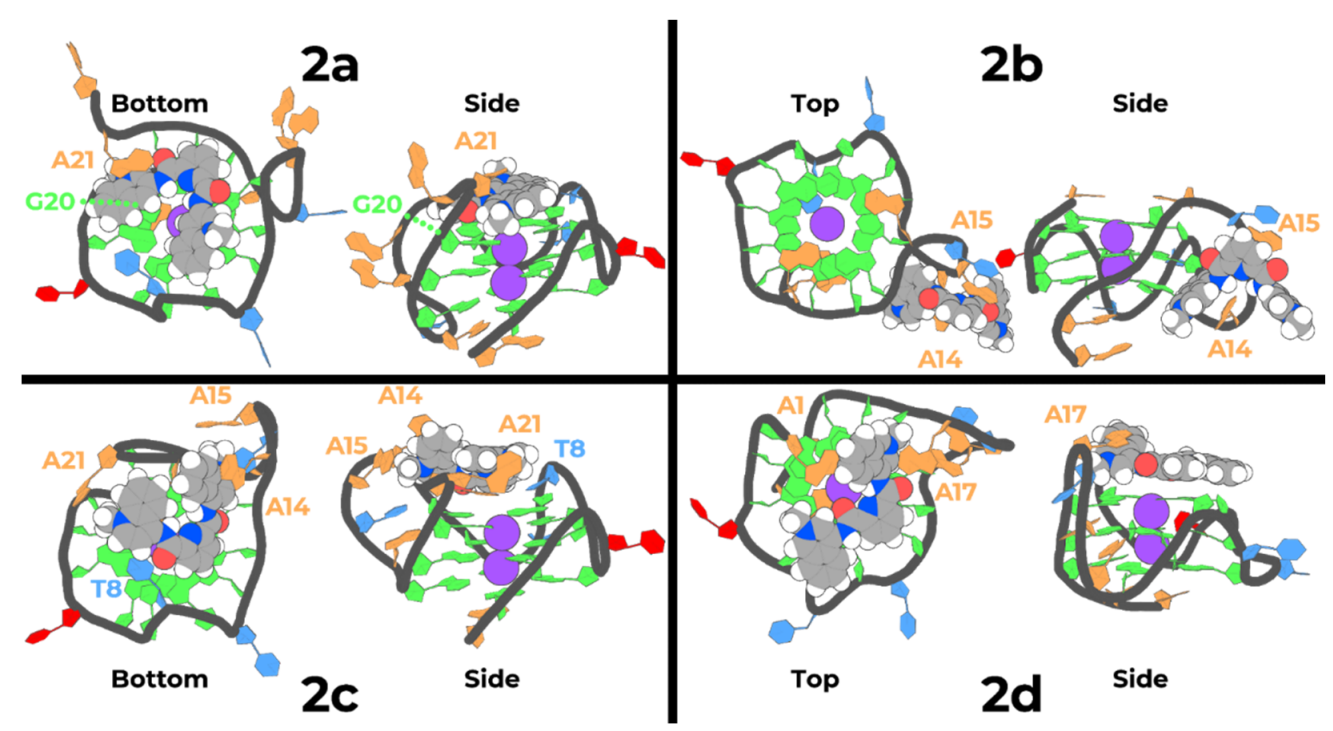

Figure 6. Snapshots of the representative lowest binding energy pose of each compound to parallel $k$-RAS G4 (top or bottom views on the left and side views on the right). The backbone of $k$-RAS G4 molecule is represented as black cartoon, and all the side-chains of the pairs of bases are differently colored with filled lines and sticks: guanines are colored in green, adenines in orange, thymines in blue and cytosines in red.

Table 4. Average binding free energy of the representative configurations of the different compounds with the $k$-RAS G4 (PDB ID: PDB 5i2v). Fifty snapshots were used in the calculations.

\begin{tabular}{cccccc}
\hline Ligand & $\begin{array}{c}\text { Average } \\
\text { Binding Free } \\
\text { Energy } \\
\mathbf{( k J / m o l )}\end{array}$ & $\begin{array}{c}\text { Van der Waals } \\
\text { Energy } \\
\mathbf{( k J / m o l )}\end{array}$ & $\begin{array}{c}\text { Electrostatic } \\
\text { Energy } \\
\mathbf{( k J / m o l )}\end{array}$ & $\begin{array}{c}\text { Polar Solvation } \\
\text { Energy } \\
\mathbf{( k J / m o l )}\end{array}$ & $\begin{array}{c}\text { SASA Energy } \\
\mathbf{( k J} / \mathbf{m o l})\end{array}$ \\
\hline $\mathbf{2 a}$ & $-207 \pm 8$ & $-240 \pm 6$ & $-560 \pm 4$ & $612 \pm 13$ & $-19 \pm 1$ \\
$\mathbf{2 b}$ & $-215 \pm 14$ & $-220 \pm 5$ & $-518 \pm 4$ & $543 \pm 17$ & $-19 \pm 1$ \\
$\mathbf{2 c}$ & $-171 \pm 8$ & $-248 \pm 8$ & $-553 \pm 4$ & $649 \pm 9$ & $-19 \pm 1$ \\
$\mathbf{2 d}$ & $-203 \pm 7$ & $-217 \pm 7$ & $-521 \pm 5$ & $551 \pm 14$ & $-17 \pm 1$ \\
\hline
\end{tabular}

The previously described interaction observed in compound $\mathbf{2 a}$ is completely distinct from the interaction observed in the representative lowest binding affinity conformation of compound $\mathbf{2} \mathbf{b}$ with $k$-RAS. As can be seen in Figure 6 , compound $\mathbf{2} \mathbf{b}$ directly interacts on a side groove of $k-R A S$ between adenine 15 and guanine 19. In this conformation, the pyridine group of the compound stacks with adenine 15, with both the isoquinolines showing a $90^{\circ}$ rotation of the aromatic groups in respect to the plane of the pyridine group. This configuration allows for one of the isoquinolines to stack with the aromatic region of adenine 14 and with the $\mathrm{N}$-methylated group facing the phosphorus of guanine 20 . The other isoquinoline faces the solvent, exposing the $N$-methylated group to the environment water molecules. This configuration, although showing a good binding free energy to $k$-RAS (see Table 4), is in a completely different interaction configuration when compared to compound 2a. Moreover, it is also possible to find interaction configurations of compound $\mathbf{2} \mathbf{b}$ in a similar configuration to the one previously described for compound $\mathbf{2 a}$ (stacked at the top and bottom regions of $k-R A S$ ). However, these configurations are of much higher binding free energy, which could be correlated with its lower ability to stabilize $k-R A S$.

Regarding the representative lowest binding affinity configuration for compound 2c (Figure 6) we can see that, similarly to compound 2a, this compound stacks at the bottom of the $k-R A S \mathrm{G} 4$. Both the pyridine and quinoline groups of this compound are stacked with the central guanine tetrads. Additionally, the positive $N$-methylated groups in quinolines are also facing the phosphate backbone of G4, establishing strong favorable electrostatic interactions (Table 4). However, while compound 2a shows a full planar 
interaction configuration at top of the G4 molecule, in compound $2 \mathrm{c}$ only one quinoline is fully stacked with adenine 21, while the other quinoline evidences a twisted conformation which ultimately results in a less stable configuration when compared to compound 2a.

Finally, in what concerns compound $\mathbf{2 d}$, similarly to what was observed for compounds $\mathbf{2 a}$ and $\mathbf{2 c}$, the lowest binding affinity representative conformation is found stacking on the top of the $k$-RAS G4 in a very similar configuration as the one adopted by compound 2c. The major difference observed from these two compounds comes from the more planar conformation with the guanine-rich core of $k-R A S$, which is further stabilized by stacking with adenine 17. Additionally, both the $N$-methylated groups seem to adjust in order to assure that a favorable electrostatic interaction with the negatively charged phosphate groups of the DNA backbone is achieved. This interaction configuration seems to allow compound $2 \mathbf{d}$ to interact and stabilize $k-R A S$ to a greater extent when compared to compound $\mathbf{2 c}$.

To try to correlate the binding free energies of the representative configurations of the different compounds with the experimental melting temperature assay results, we have calculated the average binding free energy of the different compounds with the 50 more similar configurations to the previously analyzed representative solutions (based on RMSD differences). As can be seen in Table 4, compound $\mathbf{2 b}$ stands out as the one showing a higher binding free energy to the $k-R A S$ G4. However, one should mention that the interaction configurations showing these binding free energy values correspond to quite different configurations in respect to those observed for all the other compounds.

Another fact that is possible to identify from the analysis of Table 4, is that the electrostatic energies are the forces that most contribute to the overall binding free energies, which most probably come from the previously described electrostatic interactions observed between the $N$-methylated groups of the quinolines/isoquinolines and the backbone phosphates of the DNA. Overall, the representative interaction configurations identified from the MD simulations for compounds $\mathbf{2 a}, \mathbf{2} \mathbf{c}$ and $\mathbf{2 d}$ show a clear stacking of the pyridine and quinoline/isoquinoline groups with the guanine tetrad at the core of $k$-RAS G4, with the positive $\mathrm{N}$-methylated groups of the quinolines/isoquinolines interacting with the negative G4-DNA phosphates. The small conformational differences observed between the different compounds with G4, which consequently are responsible for the determined differences in the binding free energies, seem to come from the degree of achieved planarity between the aromatic groups. Except for compound $\mathbf{2 b}$, the binding results obtained can directly be correlated with the results from the melting temperature assays previously described, reporting compound 2a as the one with a higher ability to stabilize $k$-RAS G4 when compared to compounds $2 \mathbf{d}$ and $\mathbf{2 c}$, respectively. However, one should recall that binding free energies only evaluate the binding and should not be directly correlated with the stabilization effect of the different compounds on the full G4. Therefore, despite the fact that we were able to get a good correlation between the binding affinities and the melting temperature assays for compounds $\mathbf{2 a}, \mathbf{2 c}$ and $\mathbf{2 d}$, the results obtained for compound $\mathbf{2 b}$ evidence the need for a careful and comparative analysis of the determined binding affinity results and the overall stabilization of the G4 determined by the temperature melting assays.

\section{Materials and Methods}

\subsection{Synthesis of Compounds}

3.1.1. General Procedure A for Synthesis of

Bis-quinolinyl/isoquinolinyl-pyridine-2,6-dicarboxamides (1b-h)

In a round-bottom flask, a mixture of aminoquinoline/amino-isoquinoline $(70 \mathrm{mg}$, $0.60 \mathrm{mmol}$ ) and pyridine-2,6-dicarbonyl-dichloride (50 $\mathrm{mg}, 0.245 \mathrm{mmol})$ was refluxed overnight in $2.0 \mathrm{~mL}$ of freshly dried toluene. The resulting precipitate was recovered by suction filtration, then washed with acetone and a $5 \%$ aqueous solution of $\mathrm{NaHCO}_{3}$ to obtain the titled compound (1)-1h) as a white powder with a yield of $50-95 \%$.

$N^{2}, N^{6}$-di(Quinolin-2-yl)pyridine-2,6-dicarboxamide (1a). 2-aminoquinoline $(77.75 \mathrm{mg}$, $0.539 \mathrm{mmol})$ was dissolved in $3 \mathrm{~mL}$ of THF and $93.92 \mu \mathrm{L}$ of DIPEA $(0.539 \mathrm{mmol})$ added to the mixture. Pyridine-2,6-dicarbonyl-dichloride $(50 \mathrm{mg}, 0.245 \mathrm{mmol})$ was finally added to 
the solution refluxed for $24 \mathrm{H}$. The solvent was then removed in vacuum and the product purified by flash chromatography (100 Hexane to 3:7 Hexane/EtOAc) to give a light brown powder in a yield of $60 \% .{ }^{1} \mathrm{H}$ NMR $\left(\mathrm{CDCl}_{3}\right) \delta 11.27(\mathrm{~s}, 2 \mathrm{H}), 8.63(\mathrm{~d}, \mathrm{~J}=8.7 \mathrm{~Hz}, 2 \mathrm{H}), 8.45(\mathrm{~d}$, $\mathrm{J}=7.8 \mathrm{~Hz}, 2 \mathrm{H}), 8.18(\mathrm{~d}, \mathrm{~J}=9.0 \mathrm{~Hz}, 2 \mathrm{H}), 8.08(\mathrm{t}, \mathrm{J}=7.8 \mathrm{~Hz}, 1 \mathrm{H}), 7.90(\mathrm{~d}, \mathrm{~J}=8.4 \mathrm{~Hz}, 2 \mathrm{H}), 7.74$ $(\mathrm{d}, \mathrm{J}=7.9 \mathrm{~Hz}, 2 \mathrm{H}), 7.64(\mathrm{t}, \mathrm{J}=7.7 \mathrm{~Hz}, 2 \mathrm{H}), 7.42(\mathrm{t}, \mathrm{J}=7.5 \mathrm{~Hz}, 2 \mathrm{H}) .{ }^{13} \mathrm{C} \mathrm{NMR}\left(\mathrm{CDCl}_{3}\right) \delta 162.18$, 150.87, 148.54, 146.26, 139.50, 139.00, 130.20, 127.60, 127.44, 126.38, 125.96, 125.51, 114.50 . ESI-MS $m / z(100 \%) 420.2\left([\mathrm{M}+\mathrm{H}]^{+}\right)$, HPLC-MS: RT $=3.41 \mathrm{~min}$. Calculated purity $87 \%$.

$N^{2}, N^{6}$-di(Quinolin-5-yl)pyridine-2,6-dicarboxamide (1b). The title compound was synthesized following the general synthetic procedure A, reacting pyridine-2,6-dicarbonyldichloride with 5-aminoquinoline, with a final yield of $89 \% .{ }^{1} \mathrm{H}$ NMR (DMSO-d6) $\delta 11.48$ $(\mathrm{s}, 2 \mathrm{H}, \mathrm{NH}), 8.97(\mathrm{~d}, \mathrm{~J}=2.4 \mathrm{~Hz}, 2 \mathrm{H}), 8.57-8.43(\mathrm{~m}, 4 \mathrm{H}), 8.37(\mathrm{dd}, \mathrm{J}=7.2,7.8 \mathrm{~Hz}, 1 \mathrm{H}), 8.02$ $(\mathrm{d}, \mathrm{J}=8.1 \mathrm{~Hz}, 2 \mathrm{H}), 7.92-7.77(\mathrm{~m}, 4 \mathrm{H}), 7.64(\mathrm{dd}, \mathrm{J}=9.0,6.0 \mathrm{~Hz}, 2 \mathrm{H}) .{ }^{13} \mathrm{C}$ NMR (DMSO-d6) $\delta$ 163.21, 151.32, 148.96, 148.59, 140.69, 133.76, 132.75, 129.59, 128.19, 125.96, 125.00, 124.96, 121.92. ESI-MS $m / z(100 \%) 171.1,420.2\left([\mathrm{M}+\mathrm{H}]^{+}\right)$. HPLC-MS RT $=3.50 \mathrm{~min}$. Calculated purity $98 \%$.

$N^{2}, N^{6}$-di(Quinolin-3-yl)pyridine-2,6-dicarboxamide (1c). The title compound was synthesized following the general synthetic procedure $\mathrm{A}$, reacting pyridine-2,6-dicarbonyldichloride with 3-aminoquinoline, with a final yield of 70\%. ${ }^{1} \mathrm{H}$ NMR (DMSO-d6) $\delta 9.39(\mathrm{~d}$, $\mathrm{J}=2.5 \mathrm{~Hz}, 2 \mathrm{H}), 8.98(\mathrm{~d}, \mathrm{~J}=2.5 \mathrm{~Hz}, 2 \mathrm{H}), 8.47(\mathrm{~d}, \mathrm{~J}=7.6 \mathrm{~Hz}, 2 \mathrm{H}), 8.36(\mathrm{dd}, \mathrm{J}=7.8,6.9 \mathrm{~Hz}, 1 \mathrm{H})$, $8.03(\mathrm{~d}, \mathrm{~J}=8.1 \mathrm{~Hz}, 4 \mathrm{H}), 7.71(\mathrm{td}, \mathrm{J}=9.0,1,2 \mathrm{~Hz}, 2 \mathrm{H}), 7.63(\mathrm{td}, \mathrm{J}=9.0,1.0 \mathrm{~Hz}, 2 \mathrm{H}) .{ }^{13} \mathrm{C}$ NMR (DMSO-d6) $\delta 162.94,148.93,146.55,145.12,140.72,132.41,129.11,128.87,128.40,128.16$, $127.64,126.12,124.88$. ESI-MS $m / z(100 \%) 171.1,420.2\left([\mathrm{M}+\mathrm{H}]^{+}\right)$. HPLC-MS, RT= $3.19 \mathrm{~min}$. Calculated purity $96 \%$.

$N^{2}, N^{6}$-di(Quinolin-6-yl)pyridine-2,6-dicarboxamide (1d). The title compound was synthesized following the general synthetic procedure A, reacting pyridine-2,6-dicarbonyldichloride with 6-aminoquinoline, with a final yield of $69 \%$. ${ }^{1} \mathrm{H}$ NMR (DMSO-d6) $\delta 11.39$ (s, $2 \mathrm{H}, \mathrm{NH}), 8.86(\mathrm{dd}, \mathrm{J}=4.2,1.6 \mathrm{~Hz}, 2 \mathrm{H}), 8.73(\mathrm{~d}, \mathrm{~J}=2.2 \mathrm{~Hz}, 2 \mathrm{H}), 8.49(\mathrm{~d}, 2 \mathrm{H}), 8.43(\mathrm{dd}, \mathrm{J}=7.6$, $2.3 \mathrm{~Hz}, 2 \mathrm{H}), 8.37(\mathrm{t}, \mathrm{J}=8.6,6.8 \mathrm{~Hz}, 1 \mathrm{H}), 8.26(\mathrm{dd}, \mathrm{J}=9.1,2.3 \mathrm{~Hz}, 2 \mathrm{H}), 8.13(\mathrm{~d}, \mathrm{~J}=9.1 \mathrm{~Hz}, 2 \mathrm{H})$, $7.56(\mathrm{dd}, \mathrm{J}=8.3,4.2 \mathrm{~Hz}, 2 \mathrm{H}) .{ }^{13} \mathrm{C}$ NMR (DMSO-d6) $\delta 162.53,150.03,149.15,145.48,140.68$, $136.49,136.40,129.87,128.69,126.12,125.40,122.44,117.72$. ESIMS $m / z(100 \%) 171.1,420.2$ $\left([\mathrm{M}+\mathrm{H}]^{+}\right)$. HPLC-MS, RT $=3.34 \mathrm{~min}$. Calculated purity $96 \%$.

$N^{2}, N^{6}$-di(Quinolin-4-yl)pyridine-2,6-dicarboxamide (1e). The title compound was synthesized following the general synthetic procedure $\mathrm{A}$, reacting pyridine-2,6-dicarbonyldichloride with 4-aminoquinoline with a final yield of 50\%. ${ }^{1} \mathrm{H}$ NMR (DMSO-d6) $\delta 11.59$ $(\mathrm{s}, 2 \mathrm{H}, \mathrm{NH}), 8.98(\mathrm{~d}, \mathrm{~J}=4.9 \mathrm{~Hz}, 2 \mathrm{H}), 8.53(\mathrm{~d}, \mathrm{~J}=7.5 \mathrm{~Hz}, 2 \mathrm{H}), 8.46-8.35(\mathrm{~m}, 3 \mathrm{H}), 8.10(\mathrm{~d}$, $\mathrm{J}=8.5 \mathrm{~Hz}, 2 \mathrm{H}), 8.01(\mathrm{~d}, \mathrm{~J}=4.9 \mathrm{~Hz}, 2 \mathrm{H}), 7.86(\mathrm{td}, \mathrm{J}=7.8,1.4 \mathrm{~Hz}, 2 \mathrm{H}), 7.75(\mathrm{td}, \mathrm{J}=7.7,1.4 \mathrm{~Hz}$, 2H). ${ }^{13}$ C NMR (DMSO-d6) $\delta 163.92,152.21,150.16,149.71,142.34,141.83,131.31,130.73$, 127.82, 127.53, 124.70, 124.21, 117.23. ESI-MS $m / z(100 \%)$ 171.1, $420.2\left([\mathrm{M}+\mathrm{H}]^{+}\right)$, HPLC-MS, $\mathrm{RT}=2.94 \mathrm{~min}$. Calculated purity $98 \%$.

$N^{2}, N^{6}$-di(Quinolin-8-yl)pyridine-2,6-dicarboxamide (1f). The title compound was synthesized following the general synthetic procedure $\mathrm{A}$, reacting pyridine-2,6-dicarbonyldichloride with 8-aminoquinoline with a final yield of $94 \% .{ }^{1} \mathrm{H}$ NMR $\left(\mathrm{CDCl}_{3}\right) \delta 12.38(\mathrm{~s}$, $2 \mathrm{H}, \mathrm{NH}), 9.04(\mathrm{dd}, \mathrm{J}=7.0,2.0 \mathrm{~Hz}, 2 \mathrm{H}), 8.60(\mathrm{~d}, \mathrm{~J}=7.8 \mathrm{~Hz}, 2 \mathrm{H}), 8.28(\mathrm{dd}, \mathrm{J}=4.2,1.7 \mathrm{~Hz}$, $2 \mathrm{H}), 8.25-8.17(\mathrm{~m}, 3 \mathrm{H}), 7.75-7.59(\mathrm{~m}, 4 \mathrm{H}), 7.35(\mathrm{dd}, \mathrm{J}=8.2,4.2 \mathrm{~Hz}, 2 \mathrm{H}) .{ }^{13} \mathrm{C} \mathrm{NMR}\left(\mathrm{CDCl}_{3}\right) \delta$ 162.01, 149.86, 148.70, 139.60, 139.34, 136.14, 134.42, 128.06, 127.37, 125.43, 122.35, 121.42, 117.28. ESI-MS $m / z(100 \%) 171.1,420.2\left([\mathrm{M}+\mathrm{H}]^{+}\right)$, HPLC-MS, RT $=3.24$ min. Calculated purity $94 \%$

$N^{2}, N^{6}$-di(Isoquinolin-4-yl)pyridine-2,6-dicarboxamide (1g). The title compound was synthesized following the general synthetic procedure $\mathrm{A}$, reacting pyridine-2,6dicarbonyl-dichloride with 4-amino-isoquinoline with a final yield of $56 \%$. ${ }^{1} \mathrm{H}$ NMR (DMSO-d6) $\delta 11.46(\mathrm{~s}, 2 \mathrm{H}, \mathrm{NH}), 9.34(\mathrm{~s}, 2 \mathrm{H}), 8.71(\mathrm{~s}, 2 \mathrm{H}), 8.48(\mathrm{~d}, \mathrm{~J}=8.4 \mathrm{~Hz}, 2 \mathrm{H}), 8.38(\mathrm{dd}, \mathrm{J}$ $=9.0,6.5 \mathrm{~Hz}, 2 \mathrm{H}), 8.25(\mathrm{~d}, \mathrm{~J}=8.4 \mathrm{~Hz}, 2 \mathrm{H}), 8.11(\mathrm{~d}, \mathrm{~J}=8.4 \mathrm{~Hz}, 2 \mathrm{H}), 7.91(\mathrm{td}, \mathrm{J}=8.4,1.3 \mathrm{~Hz}$, 2H), $7.78(\mathrm{td}, \mathrm{J}=8.1,1.2 \mathrm{~Hz}, 2 \mathrm{H}) .{ }^{13} \mathrm{C}$ NMR (DMSO-d6) $\delta 163.45,151.47,148.85,141.43$, 
$140.73,140.40,132.45,131.32,128.98,128.63,128.35,126.05,123.08$. ESI-MS $m / z(100 \%)$ 171.1, $420.2\left([\mathrm{M}+\mathrm{H}]^{+}\right)$, HPLC-MS, RT= $2.89 \mathrm{~min}$. Calculated purity $83 \%$.

$N^{2}, N^{6}$-di(Isoquinolin-5-yl)pyridine-2,6-dicarboxamide (1h). The title compound was synthesized following the general synthetic procedure A, reacting pyridine-2,6dicarbonyl-dichloride with 5-aminoisoquinoline with a final yield of $66 \%$. ${ }^{1} \mathrm{H}$ NMR (DMSOd6) $\delta 11.46(\mathrm{~s}, 2 \mathrm{H}, \mathrm{NH}), 9.40(\mathrm{~d}, \mathrm{~J}=1.2 \mathrm{~Hz}, 2 \mathrm{H}), 8.60(\mathrm{~d}, \mathrm{~J}=6.0 \mathrm{~Hz}, 2 \mathrm{H}), 8.47$ (d, J = 7.7 Hz, $2 \mathrm{H}), 8.38(\mathrm{dd}, \mathrm{J}=8.8,6.5 \mathrm{~Hz}, 1 \mathrm{H}), 8.18(\mathrm{~d}, \mathrm{~J}=6 \mathrm{~Hz}, 2 \mathrm{H}), 7.99(\mathrm{dd}, \mathrm{J}=8.2,1.2 \mathrm{~Hz}, 2 \mathrm{H}), 7.95$ $(\mathrm{d}, \mathrm{J}=6.0 \mathrm{~Hz}, 2 \mathrm{H}), 7.80(\mathrm{t}, \mathrm{J}=8.2 \mathrm{~Hz}, 2 \mathrm{H}) .13 \mathrm{C}$ NMR (DMSO-d6) $\delta 163.18,153.09,148.93$, $143.52,140.72,132.74,132.15,129.25,128.77,127.77,126.85,126.00,116.89$. ESI-MS $m / z$ $(100 \%) 420.2\left([\mathrm{M}+\mathrm{H}]^{+}\right)$. HPLC-MS, RT = $3.36 \mathrm{~min}$. Calculated purity $95 \%$.

3.1.2. General Procedure B for Synthesis of

Bis-methyl-quinolinium/isoquinolinium-pyridine 2,6-Dicarboxamides (2a-d)

In a round-bottom flask, $50 \mathrm{mg}$ of pyridine-2,6-dicarboxamide $\mathbf{1 c}, \mathbf{1 e}, \mathbf{1 g}$, or $\mathbf{1 h}$, $0.119 \mathrm{mmol}$ ) were dissolved in $1.5 \mathrm{~mL}$ of a mixture DMF:Acetone (1:1). $148.5 \mu \mathrm{L}$ of $\mathrm{CH}_{3} \mathrm{I}$ were added to the reaction mixture, which was stirred for 5 days at room temperature. The resulting yellow precipitate was filtered and washed with cold $\mathrm{MeOH}$ to obtain the methylated bis-quinolinium/isoquinolinium iodide (2a-2d) with a yield of $50-60 \%$.

3,3'-((Pyridine-2,6-dicarbonyl)bis(azanediyl))bis(1-methylquinolin-1-ium) Iodide (2a) This compound was synthesized from 1c $(0.119 \mathrm{mmol})$ according to general procedure $\mathrm{B}$, to give the title compound in 61\% yield. ${ }^{1} \mathrm{H}$ NMR (DMSO-d6) $\delta 11.83(\mathrm{~s}, 2 \mathrm{H}$, $\mathrm{NH}), 10.13(\mathrm{~s}, 2 \mathrm{H}), 9.67(\mathrm{~s}, 2 \mathrm{H}), 8.62-8.53(\mathrm{~m}, 6 \mathrm{H}), 8.49(\mathrm{t}, \mathrm{J}=7.7 \mathrm{~Hz}, 1 \mathrm{H}), 8.24(\mathrm{t}, \mathrm{J}=7.5 \mathrm{~Hz}$, $2 \mathrm{H}), 8.08(\mathrm{t}, \mathrm{J}=7.6 \mathrm{~Hz}, 2 \mathrm{H}), 4.80(\mathrm{~s}, 6 \mathrm{H}) .{ }^{13} \mathrm{C}$ NMR (DMSO-d6) $\delta 162.5,147.5,144.7,141.2$, $135.9,134.5,134.1,132.3,130.5,129.9,129.3,126.5,122.8,119.3,118.5,49.2$. NMR data in agreement with previously reported in [45].). ESI-MS $m / z(100 \%) 185.2,448.3\left([\mathrm{M}-\mathrm{H}-2 \mathrm{I}]^{+}\right)$. HPLC-MS, RT = 2.83 min. Calculated purity $>90 \%$

5,5'-((Pyridine-2,6-dicarbonyl)bis(azanediyl))bis(2-methylisoquinolin-2-ium) Iodide (2b) was obtained from $1 \mathrm{~h}(0.119 \mathrm{mmol})$ according to general procedure $\mathrm{B}$, with a final yield of 56\%. ${ }^{1} \mathrm{H}$ NMR (DMSO-d6) $\delta 11.65$ (s, 2H, NH), $10.10(\mathrm{~s}, 2 \mathrm{H}), 8.74$ (d, J = 6.6 $\mathrm{Hz}, 2 \mathrm{H}), 8.65(\mathrm{~d}, \mathrm{~J}=6.9 \mathrm{~Hz}, 2 \mathrm{H}), 8.55-8.38(\mathrm{~m}, 7 \mathrm{H}), 8.18(\mathrm{t}, \mathrm{J}=7.9 \mathrm{~Hz}, 2 \mathrm{H}), 4.52(\mathrm{~s}, 6 \mathrm{H})$. ${ }^{13}$ C NMR (DMSO-d6) $\delta$ 163.36, 151.61, 148.55, 141,11 (Detected via HMQC), 136.19, 134.22, 133.77, 133.34, 131.77, 129.33, 128.29, 126.40, 122.82, 48.46. ESI-MS $m / z$ (100\%) 185.2, 448.3 $\left([\mathrm{M}-\mathrm{H}-2 \mathrm{I}]^{+}\right), \mathrm{HPLC}-\mathrm{MS}, \mathrm{RT}=2.83 \mathrm{~min}$. Calculated purity $96 \%$.

4, ' $^{\prime}$-((Pyridine-2,6-dicarbonyl)bis(azanediyl))bis(1-methylquinolin-1-ium) Iodide (2c) was obtained from 1 e $(0.119 \mathrm{mmol})$ according to general procedure $\mathrm{B}$, with a final $51 \%$ yield. ${ }^{1} \mathrm{H}$ NMR (DMSO-d6) $\delta 12.10(\mathrm{~s}, 2 \mathrm{H}), 9.45(\mathrm{~d}, \mathrm{~J}=6.9 \mathrm{~Hz}, 2 \mathrm{H}), 9.11$ (d, J = 8.5 Hz, 2H), $8.79(\mathrm{~d}, \mathrm{~J}=6.8 \mathrm{~Hz}, 2 \mathrm{H}), 8.68(\mathrm{~d}, \mathrm{~J}=7.7 \mathrm{~Hz}, 2 \mathrm{H}), 8.61-8.47(\mathrm{~m}, 3 \mathrm{H}), 8.34(\mathrm{t}, \mathrm{J}=7.5 \mathrm{~Hz}, 2 \mathrm{H})$, $8.08(\mathrm{t}, \mathrm{J}=7.7 \mathrm{~Hz}, 2 \mathrm{H}), 4.56(\mathrm{~s}, 6 \mathrm{H}) .{ }^{13} \mathrm{C}$ NMR (DMSO-d6) $163.84(\mathrm{C}=\mathrm{O}), 150.73(\mathrm{CH}), 148.13$ (C), $141.35(\mathrm{CH}), 139.95(\mathrm{C}), 135.76(\mathrm{CH}), 129.09(\mathrm{CH}), 128.19(\mathrm{CH}), 125.91(\mathrm{CH}), 125.60$ (C), $121.96(\mathrm{C}), 119.98(\mathrm{CH}), 112.56(\mathrm{CH}), 45.16$ (CH3). ESI-MS $m / z$ (100\%) 185.2, 448.3 $\left([\mathrm{M}-\mathrm{H}-2 \mathrm{I}]^{+}\right), \mathrm{HPLC}-\mathrm{MS}, \mathrm{RT}=2.83 \mathrm{~min}$. Calculated purity $95 \%$.

4,4'-((Pyridine-2,6-dicarbonyl)bis(azanediyl))bis(2-methylisoquinolin-2-ium) Iodide (2d) was obtained from $1 \mathrm{~g}(0.119 \mathrm{mmol})$ according to general procedure $\mathrm{B}$, stirring for 2 days, with a final $51 \%$ yield.

${ }^{1} \mathrm{H}$ NMR (DMSO-d6) $\delta 11.78$ (s, 2H), 9.97 (s, 2H), $9.21(\mathrm{~s}, 2 \mathrm{H}), 8.65(\mathrm{~d}, \mathrm{~J}=8.5 \mathrm{~Hz}, 2 \mathrm{H})$, $8.58(\mathrm{~d}, \mathrm{~J}=7.6 \mathrm{~Hz}, 4 \mathrm{H}), 8.52-8.46(\mathrm{~m}, 1 \mathrm{H}), 8.39(\mathrm{t}, \mathrm{J}=7.8 \mathrm{~Hz}, 2 \mathrm{H}), 8.17(\mathrm{t}, \mathrm{J}=7.7 \mathrm{~Hz}, 2 \mathrm{H}), 4.56$ (s, 6H). ${ }^{13} \mathrm{C}$ NMR (DMSO-d6) $\delta 163.34,148.94,148.17,141.30$ (Detected in HMQC), 136.99, 132.87, 132.84, 132.68, 132.09, 131.10, 128.04, 127.06, 123.94, 48.95. ESI-MS m/z (100\%) 185.2, $448.3\left([\mathrm{M}-\mathrm{H}-2 \mathrm{I}]^{+}\right)$, HPLC-MS, RT = $2.83 \mathrm{~min}$. Calculated purity $97 \%$.

\subsection{PCR-Stop Assay}

The protocol for PCR-Stop assay and the primer design was adapted from a previously reported protocol [52]. For the complete sequence list, refer to Supplementary Table S3. Briefly, for each reaction, $0.5 \mu \mathrm{L}$ of Taq DNA Polymerase (New England Biolabs (NEB), Inc., Ipswich, MA, USA), $2.0 \mu \mathrm{L}$ of ThermoPol ${ }^{\circledR}$ buffer $\left(20 \mathrm{mM}\right.$ Tris- $\mathrm{HCl}, 10 \mathrm{mM}(\mathrm{NH} 4)_{2} \mathrm{SO}_{4}$, 
$10 \mathrm{mM} \mathrm{KCl}, 2 \mathrm{mM} \mathrm{MgSO} 4,0.1 \%$ Triton $\left.^{\circledR} \mathrm{X}-100, \mathrm{pH} 8.8 @ 25{ }^{\circ} \mathrm{C}, \mathrm{NEB}\right), 1.0 \mu \mathrm{L}$ of dNTP mix (10 mM each dNTP, NEB), $1.0 \mu \mathrm{L}$ of each primer (straight + reverse, $25 \mu \mathrm{M}$, STAB VIDA, Caparica, Portugal) solutions were added, for a total volume of $5.5 \mu \mathrm{L}$. Water, Sigma-HPLC grade, and the tested compound are added to a final volume of $20 \mu \mathrm{L}$. PCR conditions: $94{ }^{\circ} \mathrm{C}$ for $3 \mathrm{~min}$, followed by 10 cycles of $94^{\circ} \mathrm{C} 30 \mathrm{~s}, 58^{\circ} \mathrm{C} 30 \mathrm{~s}$, and $72{ }^{\circ} \mathrm{C} 30 \mathrm{~s}$. After the amplification, $3 \mu \mathrm{L}$ of Gel Loading Dye Bleu $(6 \times, \mathrm{NEB})$ were added. The amplified products were separated by electrophoresis in a 12\% polyacrylamide gel (Acrylamide/Bis 19:1, 40\%, NOVEX), TBE $1 \times$. The gel was stained with ethidium bromide and photographed under UV light. PCR Marker (50-766 bp, NEB) was used as molecular weight marker.

\subsection{FRET-Melting Analysis and Competition Experiments}

Working solutions of 5'-FAM/3'TAMRA- labelled oligonucleotides (please refer to Supplementary Table S1 for the complete sequence list) were freshly prepared, diluted with FRET buffer ( $60 \mathrm{mM}$ potassium cacodylate, $\mathrm{pH} 7.4)$ at a final concentration of $20 \mu \mathrm{M}$. These were diluted at $0.4 \mu \mathrm{M}$, annealed at $95^{\circ} \mathrm{C}$ for $10 \mathrm{~min}$ in a heating block, then slowly cooled to room temperature (over $1.5 \mathrm{~h}$ ). Then, $50 \mu \mathrm{L}$ of annealed DNA solution were mixed with $50 \mu \mathrm{L}$ of tested compound at the appropriate concentration, in 96-Well RT-PCR plates, with a final DNA concentration of $0.2 \mu \mathrm{M}$. Fluorescence readings were taken at intervals of $0.5^{\circ} \mathrm{C}$, in the range $31-95^{\circ} \mathrm{C}$. The advanced curve-fitting function in GraphPad Prism (nonlinear regression fit) was used for the calculation of $\Delta \mathrm{Tm}$ values. Only results with fitting $\mathrm{r}^{2}$ values $>0.75$ were considered.

For the competition experiments, the melting of the $k$-RAS G4 $(0.2 \mu \mathrm{M})$ complexed with ligand $(5 \mu \mathrm{M}$ or $0.5 \mu \mathrm{M})$ was monitored under the same conditions, including $0.4,2.0$, 10 , and $25 \mu \mathrm{M}$ of non-fluorescent double-stranded competitor 26ds DNA, using the same FRET assay conditions.

\subsection{Titration and Melting Analyses}

All CD measurements were performed at $20{ }^{\circ} \mathrm{C}$ at $10 \mu \mathrm{M}$ strand concentration of oligonucleotide in $20 \mathrm{mM}$ lithium cacodylate containing $10 \mathrm{mM} \mathrm{KCl}$ and $90 \mathrm{mM} \mathrm{LiCl}$ for h-Telo, $20 \mathrm{mM}$ lithium cacodylate containing $100 \mathrm{mM} \mathrm{LiCl}$ for $c-M Y C$, and $20 \mathrm{mM}$ lithium cacodylate containing $50 \mathrm{mM} \mathrm{KCl}$ and $50 \mathrm{mM} \mathrm{LiCl}$ for $k-R A S$. The ionic strength was tuned so that the $\mathrm{G} 4$ structures would melt around $50{ }^{\circ} \mathrm{C}$. This offers a wider temperature window where ligand-induced thermal stabilization can be studied and enables a more accurate data analysis as good baselines are obtained at both ends (low and high temperature). The sequences were annealed by heating to $95^{\circ} \mathrm{C}$ for $10 \mathrm{~min}$ followed by cooling on ice for $1 \mathrm{~h}$. For CD titration experiments, a $10 \mathrm{mM}$ stock solution of each ligand was prepared in DMSO and the required volume for each point was added directly to a $1 \mathrm{~mm}$ quartz cell containing the oligonucleotide solution. CD spectra were recorded using a Jasco J-815 spectropolarimeter equipped with a Peltier-type temperature control system (model CDF$426 \mathrm{~S} / 15)$, using an instrument scanning speed of $200 \mathrm{~nm} / \mathrm{min}$ with a response time of $1 \mathrm{~s}$ in wavelengths ranging from 200 to $340 \mathrm{~nm}$. The recording bandwidth was $1 \mathrm{~nm}$ with $1 \mathrm{~nm}$ step size. The spectra were signal averaged over four scans and baseline corrected by subtracting a buffer spectrum.

$\mathrm{CD}$ melting spectra were acquired in the temperature range of $20-100{ }^{\circ} \mathrm{C}$, with a heating rate of $1^{\circ} \mathrm{C} / \mathrm{min}$ by monitoring the ellipticity at 290 and $265 \mathrm{~nm}$ for telomeric DNA and oncogene promoters, respectively. Spectra were acquired in the presence of 1, 5, 10 and 25 molar equivalents of ligand. CD melting spectra were acquired in $20 \mathrm{mM}$ lithium cacodylate buffer supplemented with $\mathrm{KCl}$ and $\mathrm{LiCl}$ as described above, keeping a constant ionic strength of $100 \mathrm{mM}$ (total salt concentration). Data were converted into fraction folded plots, fit to a Boltzmann distribution and the melting temperatures determined from the two-state transition model (OriginPro 8). 


\subsection{Molecular Modeling}

\subsubsection{Compound Structure Preparation}

The 3D structures of $\mathbf{2 a}, \mathbf{2} \mathbf{b}, \mathbf{2} \mathbf{c}$, and $\mathbf{2} \mathbf{d}$ compounds were initially generated using the MarvinSketch (version 20.13) software from Chemaxon (http:www.chemaxon.com, accessed on 1 July 2020). The resulting geometries were then optimized at the B3LYP/6$31 G(d)$ level of theory [55-59], using Gaussian 09, Rev A.2 [60]. To derive the partial atomic charges for each compound, we have used the strategy described for GAFF [57,61], with the molecular electrostatic potentials (ESP) created for all elements at the HF/6-31G(d) [62-64] level of theory. The overall charge of each compound was set to +2 . The atomic partial charges were afterwards derived following the restrained ESP (RESP) [65] procedure, using the antechamber [66] module implemented in AmberTools19 [67].

\subsubsection{Molecular Dynamics Simulations}

All molecular mechanics/dynamics (MM/MD) simulations were performed using the GROMACS 2018.6 software package [68-70] as well as the OL15 refinement of the Amber14sb force field [71-74].

The initial structure of the $k-R A S$ molecule was taken from PDB 5i2v [75]. Four different systems were built, each consisting of the quadruplex and one of the four compounds previously parameterized. Amber topologies were built for each compound using the tleap module in AmberTools19 [67], which were subsequently converted to GROMACS format using ACPYPE [76]. Five different replicate simulations were built for each system. In each replicate, one copy of each compound was manually placed in different positions around $k$-RAS. These systems were then initially solvated using TIP3P water molecules $[77,78]$ in a dodecahedric box, and the overall system charge was neutralized by randomly replacing 17 water molecules with $\mathrm{K}+$ ions, via the gmx genion tool. Next, the systems underwent a 2-step energy minimization procedure using the steepest descent algorithm [79]: first, with no constraints, and second with hydrogen bond constraints. Velocities were then generated according to a Maxwell distribution at $298.15 \mathrm{~K}$.

Each replicate was then simulated for $750 \mathrm{~ns}$, using the particle mesh Ewald (PME) method to treat long-range electrostatic interactions $[80,81]$ with a Fourier grid spacing of $0.12 \mathrm{~nm}$ and a cutoff of $1.4 \mathrm{~nm}$ for direct contributions. Lennard-Jones interactions were calculated using a neighbor pair list with a cutoff of $1.4 \mathrm{~nm}$ and using a Verlet scheme [82]. Solute bonds were constrained using the parallel linear constraint solver P-LINCS [83], while water molecules were constrained using the SETTLE algorithm [84]. The temperature was kept at $298.15 \mathrm{~K}$ using a Nosé-Hoover thermostat $[85,86]$ with a coupling constant of 1 ps, and an isotropic Parrinello-Rahman barostat $[87,88]$ was used to keep the pressure constant at 1 bar with a coupling constant of $5 \mathrm{ps}$ and a compressibility of $4.5 \times 10^{-5} \mathrm{bar}^{-1}$.

Analyses were performed using several GROMACS tools. In addition, plots were made using Gnuplot [89] and all 3D conformations were built using PyMOL [90].

\subsubsection{MM/PBSA Calculations}

To calculate the binding free energies of the different compounds to the $k-R A S$, we have used the program g_mmpbsa developed by Kumari et al. [91,92]. Analogously to other studies [93], we have used a single trajectory approach which assumes the quadruplex and the ligand conformation in the bound and unbound states to be identical. Equations used to determine binding free energies can be found in the Supplementary Material.

\section{Conclusions}

Bis-quinoline dicarboxamides, particularly those $\mathrm{N}$-methylated, are known to be potent G4 stabilizers. In the past, the influence of the central module on compounds capacity to bind and stabilize DNA G4s was well studied [24], but in all these studies only three linking positions of the carboxamide group to quinoline ring were explored: positions 2 (pyridostatin and analogs) [94], 3 (e.g., 360A) and 6 (e.g., 307A) [15]. In this work, we synthesized new bis-quinolinyl/isoquinolinyl-2,6-pyridine dicarboxamides to 
study the influence of the position of carboxamide linker in the quinoline/isoquinoline rings on the molecular geometry and electronic distribution, and how these parameters impact on compounds' selective binding and stabilization of G4s of different topologies.

Following a simple synthetic protocol, we were able to successfully obtain six bisquinolinyl and two bis-isoquinolinyl derivatives, compounds $\mathbf{1 a}-\mathbf{h}$, with yields of $50-94 \%$ (Scheme 1). FRET melting experiments revealed that, from these, only compounds with the amide-NH linked to positions 6 (1d) and 4 (1e), that is, with a relative 1,4-position between this group and the quinoline nitrogen, showed moderate G4 stabilizing capacity, with a preference for the hybrid h-Telo G4. Similarly, it was shown that the presence of a 4-amine group in the quinoline ring of $N^{2}, N^{6}$-di(quinolin-6-yl)pyridine-2,6-dicarboxamide leads to a G4 ligand as potent as the methylated counterpart [15]. This may be explained by an increased fraction of protonated quinoline nitrogens, due to the electron donator character of amine/amide-NH in a 1,4-relative position. Upon methylation of the quinoline/isoquinoline nitrogens, all compounds became much better G4 stabilizers (1c vs. 2a, $1 \mathrm{e}$ vs. $2 \mathrm{c}, \mathbf{1 g}$ vs. $2 \mathrm{~d}$ and $\mathbf{1 h}$ vs. $2 \mathrm{~b}$ ), showing a relative potency trend of $2 \mathrm{a}>\mathbf{2 d}>\mathbf{2 c}>$ $\mathbf{2 b}$, as determined by FRET and CD-melting assays, and a general preference for parallel G4 structures. In addition, FRET-melting competition assays showed that ligands $\mathbf{2 a - 2 d}$ are selective to G4s up to around 100-fold concentration of double-stranded DNA. We have also studied by $\mathrm{CD}$ the capacity of $\mathbf{2 a}-\mathbf{2} \mathbf{d}$ to induce a G4 topology switch and block polymerase activity in a PCR-stop assay. In the conditions of the assay, compound $2 \mathbf{a}$ was able to switch the hybrid 21-nt h-Telo G4 to a parallel topology, whereas $\mathbf{2 d}$ induced an interconversion of this G4 from hybrid to an antiparallel topology. Both compounds were also able to inhibit DNA-polymerization of the primer with the G4-forming sequence present in $c-M Y C$ promoter, being $\mathbf{2} \mathbf{d}$ more selective, since $\mathbf{2} \mathbf{a}$ also inhibited the polymerization of the mutated sequence in G-tract 3.

To understand the molecular features of compounds $\mathbf{2 a - 2 d}$ behind the observed significant differences between these analogs on G4 stabilization, we performed molecular dynamic simulations using the parallel k-RAS22 G4 structure determined by NMR (PDB ID 5i2v). Figure 6 shows that the best G4 stabilizers $\mathbf{2 a}, \mathbf{2} \mathbf{c}$ and $\mathbf{2 d}$ bind to the G-quartet through $\pi-\pi$ stacking between the quinoline/isoquinoline and pyridine rings of the ligand and the guanines of the G4, as well as through favorable electrostatic interactions between the cationic quinoline/isoquinoline nitrogens and the G4 phosphate backbone. Moreover, the position of the methyl groups in relation to the pyridine-2,6-dicarboxamide central module is determinant for the overall geometry of the ligand. The best G4 stabilizer (2a) can adopt an almost planar configuration, which optimizes the $\pi-\pi$ stacking interactions, whereas the worst G4 stabilizer (the isoquinoline derivative $\mathbf{2 b}$ ) interacts preferentially with the groove of a loop of the G4, in a complete twisted configuration.

Quadruplex-interactive small molecules have a wide potential application, not only as drugs but also as sensors of quadruplex structures. With this work we increased the portfolio of G4 ligands of the pyridine-2,6-dicarboxamide family and showed that introduction of an electron donator group in position 4 of que quinoline ring increases G4 stabilization capacity of the ligands, whereas, upon $N$-methylation of the quinoline or isoquinoline rings, the relative spatial orientation of the two quinoline/isoquinoline rings determines the ligands mode and strength of binding to G4s. Overall, we report here new isomers of the potent G4 ligand 360A (2a) presenting different strengths and modes of binding to G4s, which may be important when seeking for selectivity. This was here shown by the new bis-methyl-isoquinolinium derivative $\mathbf{2} \mathbf{d}$ which is a less potent G4 stabilizer than 2a but is more selective than the latter one in blocking DNA polymerization upon stabilization of the 2-3-4-5 G4 loop-isomer of the $c-M Y C$ promoter sequence (Figure 3). Knowing the structural features of these molecules governing the binding to G4 structures is crucial for the rational development of better therapeutics and more selective G4 sensors. 
Supplementary Materials: The following are available online at https://www.mdpi.com/article/10 $.3390 /$ ph14070669/s1, Figure S1: FRET-Melting curves of h-Telo (A, blue curve) and k-RAS (B, blue curve) G4 in presence of compound $1 \mathbf{e}$ (red curves) and $\mathbf{1 d}$ (green curves) at $5 \mu \mathrm{M}$ concentration; Figure S2: FRET-Melting curves of h-Telo G4 (blue curves), in presence of increasing concentration of compounds $2 \mathbf{a}(\mathrm{A}), \mathbf{2 b}(\mathrm{B}), \mathbf{2 c}(\mathrm{C})$ and $\mathbf{2 d}(\mathrm{D})$; Figure S3: FRET-Melting curves of $k$-RAS G4 (blue curves), in presence of increasing concentration of compounds $2 \mathbf{a}(\mathrm{A}), \mathbf{2 b}(\mathrm{B}), \mathbf{2 c}(\mathrm{C})$ and $\mathbf{2 d}(\mathrm{D})$; Figure S4: FRET-Melting curves of double-stranded t-Loop (blue curves), in presence of increasing concentration of compounds $\mathbf{2 a}(\mathrm{A}), \mathbf{2 b}(\mathrm{B}), \mathbf{2 c}(\mathrm{C})$ and $\mathbf{2 d}(\mathrm{D})$; Figure S5: CD titration of $c-M Y C$ G4 in presence of increasing equivalents (0-25) of compound $2 \mathbf{a}(\mathrm{A}), \mathbf{2 b}(\mathrm{B}), \mathbf{2 c}(\mathrm{C}), \mathbf{2 d}(\mathrm{D})$; Figure S6: CD titration of $k$-RAS G4 in presence of increasing equivalents (0-25) of compound $\mathbf{2 a}(\mathrm{A}), \mathbf{2} \mathbf{b}(\mathrm{B}), \mathbf{2} \mathbf{c}(\mathrm{C})$, 2d (D); Figure S7: CD titration of $c-M Y C$ Pu27Mut in presence of increasing equivalents of compound 2a, performed in ThermoPol buffer $\left(20 \mathrm{mM}\right.$ Tris- $\mathrm{HCl}, 10 \mathrm{mM}\left(\mathrm{NH}_{4}\right)_{2} \mathrm{SO}_{4}, 10 \mathrm{mM} \mathrm{KCl}, 2 \mathrm{mM} \mathrm{MgSO}_{4}$, $0.1 \%$ Triton ${ }^{\circledR}$ X100, pH 8.8); Figure S8: (A) Results of PCR-stop assay with compounds 1a-e at $50 \mu \mathrm{M}$ and $c-M Y C$ gene promoter Pu27. (B) Results of PCR-stop assay with compound 2a and $c-M Y C$ gene promoter Pu27 or mutated $c-M Y C$ gene promoter (Pu27mut); Figure S9: Root mean square deviation (RMSD) of the complex $k-R A S+$ ligand, throughout the simulation time for each replicate simulation; Figure S10: Variation of the MM/PBSA binding free energy between the different ligands and $k-R A S$ for each replicate simulation; Figure S11: Minimum distance of compound 2a to each pair of bases of $k-R A S$ for all replicate simulations; Figure S12: Minimum distance of compound $\mathbf{2} \mathbf{b}$ to each pair of bases of $k$-RAS for all replicate simulations; Figure S13: Minimum distance of compound $2 \mathrm{c}$ to each pair of bases of $k$-RAS for all replicate simulations; Figure S14: Minimum distance of compound $\mathbf{2 d}$ to each pair of bases of $k-R A S$ for all replicate simulations. Figures S15-S25: NMR spectra of the synthesized molecules; Figures S26-S37: TIC chromatogram of samples with peak integrations and mass spectra. Table S1: Sequences used in FRET-melting experiments; Table S2: Sequences used in CD experiments; Table S3: Sequences used in PCR-stop assay.

Author Contributions: Conceptualization of the study, A.P.; synthesis, E.C. and A.P.; FRET-melting experiments, E.C. and E.M.; CD experiments, J.C. and C.C.; PCR-stop assay, E.C. and J.V.; molecular modelling, P.R.M., R.M.E. and B.L.V.; writing-review and editing, all authors. All authors have read and agreed to the published version of the manuscript.

Funding: This research was funded by European Structural \& Investment Funds through the COMPETE Program-Programa Operacional de Lisboa under Program grant LISBOA-01-0145FEDER-016405, and from Fundação para a Ciência e Tecnologia (FCT, Portugal), project grant SAICTPAC/0019/2015, UIDP/04138/2020 of iMed, UIDB/00709/2020 of CICS, PTDC/BIA-BFS/28419/2017, strategic project UIDB/04046/2020 (BioISI) and project ref. IF/00959/2015 funded by Fundo Social Europeu e Programa Operacional Potencial Humano. J.V.'s research group was financed by New England Biolabs, Inc. (Ipswich, MA, USA).

Institutional Review Board Statement: Not applicable.

Informed Consent Statement: Not applicable.

Data Availability Statement: Data is contained within the article and supplementary material.

Acknowledgments: We thank Paulo J. Costa for fruitful discussions in the parameterization of the ligands for the molecular modeling studies. We acknowledge the financial support from FCT and Portugal 2020 to the Portuguese Mass Spectrometry Network (Rede Nacional de Espectrometria de Massa-RNEM, grant number LISBOA-01-0145-FEDER-402- 022125, for the LC-MS service. E.C. acknowledges Rui Moreira for having accepted him in iMed group to work in this project, within the context of Erasmus+ programme.

Conflicts of Interest: The authors declare no conflict of interest.

\section{References}

1. Sung, H.; Ferlay, J.; Siegel, R.L.; Laversanne, M.; Soerjomataram, I.; Jemal, A.; Bray, F. Global cancer statistics 2020: GLOBOCAN estimates of incidence and mortality worldwide for 36 cancers in 185 countries. CA. Cancer J. Clin. 2021, 71, 209-249. [CrossRef]

2. Nesbit, C.E.; Tersak, J.M.; Prochownik, E.V. MYC oncogenes and human neoplastic disease. Oncogene 1999, 18, 3004-3016. [CrossRef] [PubMed]

3. Boxer, L.M.; Dang, C.V. Translocations involving c-myc and c-myc function. Oncogene 2001, 20, 5595-5610. [CrossRef]

4. Fernandez-Medarde, A.; Santos, E. Ras in Cancer and Developmental Diseases. Genes Cancer 2011, 2, 344-358. [CrossRef] 
5. Adjei, A.A. Blocking oncogenic Ras signaling for cancer therapy. J. Natl.Cancer Inst. 2001, 93, 1062-1074. [CrossRef] [PubMed]

6. Saleem, M.; Babaei, A.; Press, D. Receptor tyrosine kinase (c-Kit ) inhibitors: A potential therapeutic target in cancer cells. Drug Des. Devel. Ther. 2016, 2443-2459. [CrossRef]

7. Gustafson, W.C.; Weiss, W.A. Myc proteins as therapeutic targets. Oncogene 2010, 29, 1249-1259. [CrossRef]

8. McCormick, F. KRAS as a therapeutic target. Clin. Cancer Res. 2015, 21, 1797-1801. [CrossRef]

9. Phan, A.T.; Kuryavyi, V.; Burge, S.; Neidle, S.; Patel, D.J. Structure of an unprecedented G-quadruplex scaffold in the human c-kit promoter. J. Am. Chem. Soc. 2007, 129, 4386-4392. [CrossRef]

10. Cogoi, S.; Xodo, L.E. G-quadruplex formation within the promoter of the KRAS proto-oncogene and its effect on transcription. Nucleic Acids Res. 2006, 34, 2536-2549. [CrossRef] [PubMed]

11. Cogoi, S.; Paramasivam, M.; Spolaore, B.; Xodo, L.E. Structural polymorphism within a regulatory element of the human KRAS promoter: Formation of G4-DNA recognized by nuclear proteins. Nucleic Acids Res. 2008, 36, 3765-3780. [CrossRef]

12. Siddiqui-Jain, A.; Grand, C.L.; Bearss, D.J.; Hurley, L.H. Direct evidence for a G-quadruplex in a promoter region and its targeting with a small molecule to repress c-MYC transcription. Proc. Natl. Acad. Sci. USA 2002, 99, 11593-11598. [CrossRef] [PubMed]

13. Largy, E.; Mergny, J.-L.; Gabelica, V. Role of Alkali Metal Ions in G-Quadruplex Nucleic Acid Structure and Stability. In The Alkali Metal Ions: Their Role for Life; Sigel, A., Sigel, H., Sigel, R.K.O., Eds.; Metal Ions in Life Sciences; Springer International Publishing: Cham, Switzerland, 2016; Volume 16, pp. 203-258. ISBN 978-3-319-21755-0.

14. Phan, A.T.; Mergny, J.-L. Human telomeric DNA: G-quadruplex, i-motif and Watson-Crick double helix. Nucleic Acids Res. 2002, 30, 4618-4625. [CrossRef]

15. Pennarun, G.; Granotier, C.; Gauthier, L.R.; Gomez, D.; Hoffschir, F.; Mandine, E.; Riou, J.F.; Mergny, J.L.; Mailliet, P.; Boussin, F.D. Apoptosis related to telomere instability and cell cycle alterations in human glioma cells treated by new highly selective G-quadruplex ligands. Oncogene 2005, 24, 2917-2928. [CrossRef] [PubMed]

16. Greider, C.W. Telomere length regulation. Annu. Rev. Biochem. 1996, 65, 337-365. [CrossRef] [PubMed]

17. Murat, P.; Balasubramanian, S. Existence and consequences of G-quadruplex structures in DNA. Curr. Opin. Genet. Dev. 2014, 25, 22-29. [CrossRef]

18. Hänsel-hertsch, R.; Beraldi, D.; Lensing, S.V.; Marsico, G.; Zyner, K.; Parry, A.; Di Antonio, M.; Pike, J.; Kimura, H.; Narita, M.; et al. G-quadruplex structures mark human regulatory chromatin. Nat. Genet. 2016, 48, 1267-1272. [CrossRef] [PubMed]

19. Hänsel-Hertsch, R.; Di Antonio, M.; Balasubramanian, S. DNA G-quadruplexes in the human genome: Detection, functions and therapeutic potential. Nat. Rev. Mol. Cell Biol. 2017, 18, 279-284. [CrossRef] [PubMed]

20. Varshney, D.; Spiegel, J.; Zyner, K.; Tannahill, D.; Balasubramanian, S. The regulation and functions of DNA and RNA Gquadruplexes. Nat. Rev. Mol. Cell Biol. 2020, 21, 459-474. [CrossRef] [PubMed]

21. Cadoni, E.; De Paepe, L.; Manicardi, A.; Madder, A. Beyond small molecules: Targeting G-quadruplex structures with oligonucleotides and their analogues. Nucleic Acids Res. 2021, 1-22. [CrossRef]

22. Neidle, S. Quadruplex Nucleic Acids as Novel Therapeutic Targets. J. Med. Chem. 2016, 59, 5987-6011. [CrossRef]

23. Paulo, A.; Castillo, C.C.; Neidle, S. Targeting Promoter Quadruplex Nucleic Acids for Cancer Therapy. In Comprehensive Medicinal Chemistry III; Elsevier: Amsterdam, The Netherlands, 2017; Volume 5, pp. 308-340. ISBN 9780124095472.

24. Duarte, A.R.; Cadoni, E.; Ressurreição, A.S.; Moreira, R.; Paulo, A. Design of Modular G-quadruplex Ligands. ChemMedChem 2018, 13, 869-893. [CrossRef] [PubMed]

25. Carvalho, J.; Mergny, J.L.; Salgado, G.F.; Queiroz, J.A.; Cruz, C. G-quadruplex, Friend or Foe: The Role of the G-quartet in Anticancer Strategies. Trends Mol. Med. 2020, 26, 848-861. [CrossRef]

26. Summers, P.A.; Lewis, B.W.; Gonzalez-Garcia, J.; Porreca, R.M.; Lim, A.H.M.; Cadinu, P.; Martin-Pintado, N.; Mann, D.J.; Edel, J.B.; Vannier, J.B.; et al. Visualising G-quadruplex DNA dynamics in live cells by fluorescence lifetime imaging microscopy. Nat. Commun. 2021, 12, 1-11. [CrossRef]

27. Biffi, G.; Tannahill, D.; McCafferty, J.; Balasubramanian, S. Quantitative visualization of DNA G-quadruplex structures in human cells. Nat. Chem. 2013, 5, 182-186. [CrossRef]

28. Biffi, G.; Di Antonio, M.; Tannahill, D.; Balasubramanian, S. Visualization and selective chemical targeting of RNA G-quadruplex structures in the cytoplasm of human cells. Nat. Chem. 2014, 6, 75-80. [CrossRef]

29. De Cian, A.; DeLemos, E.; Mergny, J.-L.; Teulade-Fichou, M.-P.; Monchaud, D. Highly Efficient G-Quadruplex Recognition by Bisquinolinium Compounds. J. Am. Chem. Soc. 2007, 129, 1856-1857. [CrossRef]

30. Dhamodharan, V.; Harikrishna, S.; Jagadeeswaran, C.; Halder, K.; Pradeepkumar, P.I. Selective G-quadruplex DNA Stabilizing Agents Based on Bisquinolinium and Bispyridinium Derivatives of 1,8-Naphthyridine. J. Org. Chem. 2012, 77, 229-242. [CrossRef] [PubMed]

31. Peng, D.; Tan, J.-H.; Chen, S.-B.; Ou, T.-M.; Gu, L.-Q.; Huang, Z.-S. Bisaryldiketene derivatives: A new class of selective ligands for c-myc G-quadruplex DNA. Bioorganic Med. Chem. 2010, 18, 8235-8242. [CrossRef] [PubMed]

32. Granotier, C.; Pennarun, G.; Riou, L.; Hoffschir, F.; Gauthier, L.R.; De Cian, A.; Gomez, D.; Mandine, E.; Riou, J.F.; Mergny, J.L.; et al. Preferential binding of a G-quadruplex ligand to human chromosome ends. Nucleic Acids Res. 2005, 33, 4182-4190. [CrossRef] [PubMed]

33. Gauthier, L.R.; Granotier, C.; Hoffschir, F.; Etienne, O.; Ayouaz, A.; Desmaze, C.; Mailliet, P.; Biard, D.S.; Boussin, F.D. Rad51 and DNA-PKcs are involved in the generation of specific telomere aberrations induced by the quadruplex ligand 360A that impair mitotic cell progression and lead to cell death. Cell. Mol. Life Sci. 2012, 69, 629-640. [CrossRef] [PubMed] 
34. Monchaud, D.; Yang, P.; Lacroix, L.; Teulade-Fichou, M.P.; Mergny, J.L. A metal-mediated conformational switch controls G-quadruplex binding affinity. Angew. Chem. Int. Ed. 2008, 47, 4858-4861. [CrossRef] [PubMed]

35. Marchand, A.; Granzhan, A.; Iida, K.; Tsushima, Y.; Ma, Y.; Nagasawa, K.; Teulade-Fichou, M.P.; Gabelica, V. Ligand-induced conformational changes with cation ejection upon binding to human telomeric DNA G-quadruplexes. J. Am. Chem. Soc. 2015, 137, 750-756. [CrossRef]

36. Saintomé, C.; Alberti, P.; Guinot, N.; Lejault, P.; Chatain, J.; Mailliet, P.; Riou, J.F.; Bugaut, A. Binding properties of mono- and dimeric pyridine dicarboxamide ligands to human telomeric higher-order G-quadruplex structures. Chem. Commun. 2018, 54, 1897-1900. [CrossRef]

37. Harikrishna, S.; Kotaru, S.; Pradeepkumar, P.I. Ligand-induced conformational preorganization of loops of $c-M Y C$ G-quadruplex DNA and its implications in structure-specific drug design. Mol. Biosyst. 2017, 13, 1458-1468. [CrossRef]

38. Marcel, V.; Tran, P.L.T.; Sagne, C.; Martel-Planche, G.; Vaslin, L.; Teulade-Fichou, M.P.; Hall, J.; Mergny, J.L.; Hainaut, P.; van Dyck, E. G-quadruplex structures in TP53 intron 3: Role in alternative splicing and in production of p53 mRNA isoforms. Carcinogenesis 2011, 32, 271-278. [CrossRef]

39. Verga, D.; Hamon, F.; Poyer, F.; Bombard, S.; Teulade-Fichou, M.P. Photo-cross-linking probes for trapping G-quadruplex DNA. Angew. Chem. Int. Ed. 2014, 53, 994-998. [CrossRef] [PubMed]

40. Cadoni, E.; Manicardi, A.; Fossépré, M.; Heirwegh, K.; Surin, M.; Madder, A. Teaching photosensitizers a new trick: Red light-triggered G-quadruplex alkylation by ligand co-localization. Chem. Commun. 2021, 57, 1010-1013. [CrossRef]

41. Yang, P.; De Cian, A.; Teulade-Fichou, M.P.; Mergny, J.L.; Monchaud, D. Engineering bisquinolinium/thiazole orange conjugates for fluorescent sensing of G-quadruplex DNA. Angew. Chem. Int. Ed. 2009, 48, 2188-2191. [CrossRef]

42. Renaud De La Faverie, A.; Hamon, F.; Di Primo, C.; Largy, E.; Dausse, E.; Delaurire, L.; Landras-Guetta, C.; Toulmé, J.J.; Teulade-Fichou, M.P.; Mergny, J.L. Nucleic acids targeted to drugs: SELEX against a quadruplex ligand. Biochimie 2011, 93, 1357-1367. [CrossRef]

43. Dorazco-González, A.; Alamo, M.F.; Godoy-Alcántar, C.; Höpfl, H.; Yatsimirsky, A.K. Fluorescent anion sensing by bisquinolinium pyridine-2,6-dicarboxamide receptors in water. RSC Adv. 2014, 4, 455-466. [CrossRef]

44. Hwang, I.P.; Mailliet, P.; Hossard, V.; Riou, J.F.; Bugaut, A.; Roger, L. Investigating the effect of mono- And dimeric 360A G-quadruplex ligands on telomere stability by single telomere length analysis (STELA). Molecules 2019, 24, 577. [CrossRef]

45. Dorazco-González, A.; Höpfl, H.; Medrano, F.; Yatsimirsky, A.K. Recognition of anions and neutral guests by dicationic pyridine2,6- dicarboxamide receptors. J. Org. Chem. 2010, 75, 2259-2273. [CrossRef] [PubMed]

46. Giancola, C.; Pagano, B. Energetics of ligand binding to G-quadruplexes. Top. Curr. Chem. 2013, 330, 211-242. [CrossRef]

47. Gray, R.D.; Petraccone, L.; Trent, J.O.; Chaires, J.B. Characterization of a K+-induced conformational switch in a human telomeric DNA oligonucleotide using 2-aminopurine fluorescence. Biochemistry 2010, 49, 179-194. [CrossRef] [PubMed]

48. Dai, J.; Carver, M.; Punchihewa, C.; Jones, R.A.; Yang, D. Structure of the hybrid-2 type intramolecular human telomeric G-quadruplex in K+ solution: Insights into structure polymorphism of the human telomeric sequence. Nucleic Acids Res. 2007, 35, 4927-4940. [CrossRef] [PubMed]

49. Ambrus, A.; Chen, D.; Dai, J.; Bialis, T.; Jones, R.A.; Yang, D. Human telomeric sequence forms a hybrid-type intramolecular G-quadruplex structure with mixed parallel/antiparallel strands in potassium solution. Nucleic Acids Res. 2006, 34, $2723-2735$. [CrossRef] [PubMed]

50. Ambrus, A.; Chen, D.; Dai, J.; Jones, R.A.; Yang, D. Solution structure of the biologically relevant G-quadruplex element in the human $c-M Y C$ promoter. Implications for G-quadruplex stabilization. Biochemistry 2005, 44, 2048-2058. [CrossRef] [PubMed]

51. Mendes, E.; Cadoni, E.; Carneiro, F.; Afonso, M.B.; Brito, H.; Lavrado, J.; dos Santos, D.J.V.A.; Vítor, J.B.; Neidle, S.; Rodrigues, C.M.P.; et al. Combining 1,3-ditriazolyl-benzene and quinoline to discover a new G-quadruplex interactive small molecule active against cancer stem-like cells. ChemMedChem 2019, 14, 1325-1328. [CrossRef]

52. Lemarteleur, T.; Gomez, D.; Paterski, R.; Mandine, E.; Mailliet, P.; Riou, J.F. Stabilization of the c-myc gene promoter quadruplex by specific ligands' inhibitors of telomerase. Biochem. Biophys. Res. Commun. 2004, 323, 802-808. [CrossRef]

53. Phan, T.A.; Modi, Y.S.; Patel, D.J. Propeller-Type Parallel-Stranded G-Quadruplexes in the Human c-myc Promoter. J. Am. Chem. Soc. 2004, 126, 8710-8716. [CrossRef]

54. Mathad, R.I.; Hatzakis, E.; Dai, J.; Yang, D. c-MYC promoter G-quadruplex formed at the 50 -end of NHE III 1 element: Insights into biological relevance and parallel-stranded G-quadruplex stability. Nucleic Acids Res. 2011, 39, 9023-9033. [CrossRef] [PubMed]

55. Krishnan, R.; Binkley, J.S.; Seeger, R.; Pople, J.A. Self-consistent molecular orbital methods. XX. A basis set for correlated wave functions. J. Chem. Phys. 1980, 72, 650-654. [CrossRef]

56. McLean, A.D.; Chandler, G.S. Contracted Gaussian basis sets for molecular calculations. I. Second row atoms, Z = 11-18. J. Chem. Phys. 1980, 72, 5639-5648. [CrossRef]

57. Becke, A.D. Density-functional exchange-energy approximation with correct asymptotic behavior. Phys. Rev. A 1988, 38, 3098-3100. [CrossRef] [PubMed]

58. Lee, C.; Yang, W.; Parr, R.G. Development of the Colle-Salvetti correlation-energy formula into a functional of the electron density. Phys. Rev. B 1988, 37, 785-789. [CrossRef] [PubMed]

59. Curtiss, L.A.; McGrath, M.P.; Blaudeau, J.; Davis, N.E.; Binning, R.C.; Radom, L. Extension of Gaussian-2 theory to molecules containing third-row atoms Ga-Kr. J. Chem. Phys. 1995, 103, 6104-6113. [CrossRef] 
60. Frisch, M.J.; Trucks, G.W.; Schlegel, H.B.; Scuseria, G.E.; Robb, M.A.; Cheeseman, J.R.; Scalmani, G.; Barone, V.; Mennucci, B.; Petersson, G.A. Gaussian 09, Revision A. 02; Gaussian, Inc.: Wallingford, CT, USA, 2016; Available online: https://gaussian.com/ g09citation/ (accessed on 12 January 2021).

61. Wang, J.; Wolf, R.M.; Caldwell, J.W.; Kollman, P.A.; Case, D.A. Development and testing of a general amber force field. J. Comput. Chem. 2004, 25, 1157-1174. [CrossRef]

62. Hariharan, P.C.; Pople, J.A. The influence of polarization functions on molecular orbital hydrogenation energies. Theor. Chim. Acta 1973, 28, 213-222. [CrossRef]

63. Francl, M.M.; Pietro, W.J.; Hehre, W.J.; Binkley, J.S.; Gordon, M.S.; DeFrees, D.J.; Pople, J.A. Self-consistent molecular orbital methods. XXIII. A polarization-type basis set for second-row elements. J. Chem. Phys. 1982, 77, 3654-3665. [CrossRef]

64. Rassolov, V.A.; Ratner, M.A.; Pople, J.A.; Redfern, P.C.; Curtiss, L.A. 6-31G* basis set for third-row atoms. J. Comput. Chem. 2001, 22, 976-984. [CrossRef]

65. Bayly, C.I.; Cieplak, P.; Cornell, W.; Kollman, P.A. A well-behaved electrostatic potential based method using charge restraints for deriving atomic charges: The RESP model. J. Phys. Chem. 1993, 97, 10269-10280. [CrossRef]

66. Wang, J.; Wang, W.; Kollman, P.A.; Case, D.A. Automatic atom type and bond type perception in molecular mechanical calculations. J. Mol. Graph. Model. 2006, 25, 247-260. [CrossRef]

67. Case, D.A.; Ben-Shalom, I.Y.; Brozell, S.R.; Cerutti, D.S.; Cheatham, T.E., III; Cruzeiro, V.W.D.; Darden, T.A.; Duke, R.E.; Ghoreishi, D.G.; Giambasu, T.; et al. AMBER 2019, University of California, San Francisco. Available online: https://ambermd.org/ (accessed on 12 January 2021).

68. Berendsen, H.J.C.; van der Spoel, D.; van Drunen, R. GROMACS: A message-passing parallel molecular dynamics implementation. Comput. Phys. Commun. 1995, 91, 43-56. [CrossRef]

69. Van Der Spoel, D.; Lindahl, E.; Hess, B.; Groenhof, G.; Mark, A.E.; Berendsen, H.J.C. GROMACS: Fast, flexible, and free. J. Comput. Chem. 2005, 26, 1701-1718. [CrossRef] [PubMed]

70. Abraham, M.J.; Murtola, T.; Schulz, R.; Páll, S.; Smith, J.C.; Hess, B.; Lindahl, E. GROMACS: High performance molecular simulations through multi-level parallelism from laptops to supercomputers. SoftwareX 2015, 1-2, 19-25. [CrossRef]

71. Zgarbová, M.; Otyepka, M.; Šponer, J.; Mládek, A.; Banáš, P.; Cheatham, T.E.; Jurečka, P. Refinement of the Cornell et al. Nucleic Acids Force Field Based on Reference Quantum Chemical Calculations of Glycosidic Torsion Profiles. J. Chem. Theory Comput. 2011, 7, 2886-2902. [CrossRef] [PubMed]

72. Zgarbová, M.; Šponer, J.; Otyepka, M.; Cheatham, T.E.; Galindo-Murillo, R.; Jurečka, P. Refinement of the Sugar-Phosphate Backbone Torsion Beta for AMBER Force Fields Improves the Description of Z- and B-DNA. J. Chem. Theory Comput. 2015, 11, 5723-5736. [CrossRef]

73. Maier, J.A.; Martinez, C.; Kasavajhala, K.; Wickstrom, L.; Hauser, K.E.; Simmerling, C. ff14SB: Improving the Accuracy of Protein Side Chain and Backbone Parameters from ff99SB. J. Chem. Theory Comput. 2015, 11, 3696-3713. [CrossRef] [PubMed]

74. Allnér, O.; Nilsson, L.; Villa, A. Magnesium Ion-Water Coordination and Exchange in Biomolecular Simulations. J. Chem. Theory Comput. 2012, 8, 1493-1502. [CrossRef]

75. Kerkour, A.; Marquevielle, J.; Ivashchenko, S.; Yatsunyk, L.A.; Mergny, J.-L.; Salgado, G.F. High-resolution three-dimensional NMR structure of the KRAS proto-oncogene promoter reveals key features of a G-quadruplex involved in transcriptional regulation. J. Biol. Chem. 2017, 292, 8082-8091. [CrossRef]

76. Sousa da Silva, A.W.; Vranken, W.F. ACPYPE-AnteChamber PYthon Parser interfacE. BMC Res. Notes 2012, 5, 367. [CrossRef]

77. Jorgensen, W.L.; Chandrasekhar, J.; Madura, J.D.; Impey, R.W.; Klein, M.L. Comparison of simple potential functions for simulating liquid water. J. Chem. Phys. 1983, 79, 926-935. [CrossRef]

78. Neria, E.; Fischer, S.; Karplus, M. Simulation of activation free energies in molecular systems. J. Chem. Phys. 1996, 105, 1902-1921. [CrossRef]

79. Luenberger, D.G.; Ye, Y. Linear and Nonlinear Programming; Springer: Berlin/Heidelberg, Germany, 2008; Volume 228, pp. 213-262. ISBN 978-3-319-18841-6.

80. Darden, T.; York, D.; Pedersen, L. Particle mesh Ewald: An N.log(N) method for Ewald sums in large systems. J. Chem. Phys. 1993, 98, 10089-10092. [CrossRef]

81. Essmann, U.; Perera, L.; Berkowitz, M.L.; Darden, T.; Lee, H.; Pedersen, L.G. A smooth particle mesh Ewald method. J. Chem. Phys. 1995, 103, 8577-8593. [CrossRef]

82. Páll, S.; Hess, B. A flexible algorithm for calculating pair interactions on SIMD architectures. Comput. Phys. Commun. 2013, 184, 2641-2650. [CrossRef]

83. Hess, B. P-LINCS: A Parallel Linear Constraint Solver for Molecular Simulation. J. Chem. Theory Comput. 2008, 4, 116-122. [CrossRef] [PubMed]

84. Miyamoto, S.; Kollman, P.A. Settle: An analytical version of the SHAKE and RATTLE algorithm for rigid water models. J. Comput. Chem. 1992, 13, 952-962. [CrossRef]

85. Nosé, S. A unified formulation of the constant temperature molecular dynamics methods. J. Chem. Phys. 1984, 81, 511-519. [CrossRef]

86. Hoover, W.G. Canonical dynamics: Equilibrium phase-space distributions. Phys. Rev. A 1985, 31, 1695-1697. [CrossRef]

87. Nosé, S.; Klein, M.L. Constant pressure molecular dynamics for molecular systems. Mol. Phys. 1983, 50, 1055-1076. [CrossRef] 
88. Parrinello, M.; Rahman, A. Polymorphic transitions in single crystals: A new molecular dynamics method. J. Appl. Phys. 1981, 52, 7182-7190. [CrossRef]

89. Williams, T.; Kelley, C.; Bersch, C. Gnuplot 5.2 An Interactive Plotting Program 2019. 2019. Available online: http:/ / www.gnuplot. info (accessed on 1 January 2019).

90. DeLano, W.L. The PyMOL Molecular Graphics System, version 2.3.1; Schrodinger LLC: New York, NY, USA, 2019; Available online: http:/ / www.gnuplot.info (accessed on 10 January 2019).

91. Kumari, R.; Kumar, R.; Lynn, A. g_mmpbsa -A GROMACS Tool for High-Throughput MM-PBSA Calculations. J. Chem. Inf. Model. 2014, 54, 1951-1962. [CrossRef]

92. Baker, N.A.; Sept, D.; Joseph, S.; Holst, M.J.; McCammon, J.A. Electrostatics of nanosystems: Application to microtubules and the ribosome. Proc. Natl. Acad. Sci. USA 2001, 98, 10037-10041. [CrossRef] [PubMed]

93. Rizzo, R.C.; Aynechi, T.; Case, D.A.; Kuntz, I.D. Estimation of Absolute Free Energies of Hydration Using Continuum Methods: Accuracy of Partial Charge Models and Optimization of Nonpolar Contributions. J. Chem. Theory Comput. 2006, 2, 128-139. [CrossRef]

94. Müller, S.; Sanders, D.A.; Di Antonio, M.; Matsis, S.; Riou, J.-F.; Rodriguez, R.; Balasubramanian, S. Pyridostatin analogues promote telomere dysfunction and long-term growth inhibition in human cancer cells. Org. Biomol. Chem. 2012, $10,6537$. [CrossRef] 